Spring 4-7-2021

\title{
Protecting Sleep to Reduce Delirium in an Adult Intensive Care Unit
}

Heather Thomas

University of St. Augustine for Health Sciences, h.thomas@usa.edu

DOI: https://doi.org/10.46409/sr.BIG03616

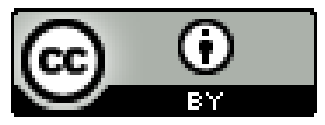

This work is licensed under a Creative Commons Attribution 4.0 License.

Follow this and additional works at: https://soar.usa.edu/scholprojects

Part of the Critical Care Nursing Commons

\section{Recommended Citation}

Thomas, H. (2021). Protecting Sleep to Reduce Delirium in an Adult Intensive Care Unit. [Doctoral project, University of St Augustine for Health Sciences]. SOAR @ USA: Student Scholarly Projects Collection. https://doi.org/10.46409/sr.BIG03616

This Scholarly Project is brought to you for free and open access by the Student Research at SOAR @ USA. It has been accepted for inclusion in Student Scholarly Projects by an authorized administrator of SOAR @ USA. For more information, please contact soar@usa.edu, erobinson@usa.edu. 
Protecting Sleep to Reduce Delirium in an Adult Intensive Care Unit

Heather J. Thomas, MSN-Ed, RN, CCRN, NPD-BC

School of Nursing, University of St. Augustine for Health Science

This Manuscript Partially Fulfills the Requirements for the

Doctor of Nursing Practice Program and is Approved by:

Sheri Jacobson, $\mathrm{PhD}, \mathrm{RN}$

Sandra Swearingen, $\mathrm{PhD}, \mathrm{RN}$

March 31, 2021 


\begin{abstract}
Practice Problem: Delirium is a common, yet often preventable complication in hospitalized patients. It is often caused by fragmented sleep, medications, environmental stimuli, and treatment therapies.
\end{abstract}

PICOT: The PICOT question that guided this evidence-based practice change project was: For patients in an adult Intensive Care Unit (ICU), does using a nurse-initiated, non-pharmacological sleep-enhancement protocol, versus no sleep-enhancement protocol, reduce the incidence of ICU-delirium over a period of 2 months?

Evidence: The reviewed literature supported the evidence for effective use of a nurse-initiated protocol in reducing delirium in the ICU. Sixteen articles met the inclusion criteria for the review of literature that supported the DNP project.

Intervention: A nurse-initiated sleep-enhancement protocol was implemented, which reduced interruptions during the hours between midnight and 0400 .

Outcome: While there was a 50\% reduction in delirious patients after the protocol was initiated, the data pool was small and was not proven to be statistically significant. Due to the Covid-19 outbreak, there were far fewer eligible patients than originally anticipated.

Conclusion: Although a clinically significant project outcome was not realized, staff felt that the protocol improved patient care and advocated for its use on all patients as a standard of care. Unit-based shared governance councils on other acute care floors have also adopted the sleep enhancement protocol 


\section{Protecting Sleep to Reduce Delirium in an Adult Intensive Care Unit}

Sleep, a critical factor in health recovery, has been noted to be fragmented in critical care settings, resulting in a correlative effect between sleep deprivation and delirium (Faraklas et al., 2013). Delirium is defined as a temporary syndrome of cognitive disability characterized by disorganized thinking and accompanied by a decreased ability to maintain attention (American Psychiatric Association, 2013). Sometimes even fatal, delirium is the most frequent complication affecting hospitalized patients over 65 years of age (Inouye et al., 2014).

Sleep deprivation in the intensive care unit (ICU) can be attributed to loud noises, bright lights, monitors, frequent assessments, mechanical ventilation, and sedative or analgesic medications (Patel et al., 2014). Delirium, while often preventable, is prevalent in the ICU and is detrimental to restoration of health (Pessoa et al., 2019). Some negative outcomes caused by ICU delirium are increased mortality, increased hospital length of stay (LOS), increased financial cost of care, and long-term cognitive impairment (Barr et al., 2013; Inouye et al., 2014). Researchers have found a correlation between the length of time a patient suffered delirium and the level of functional disability for up to a year after discharge (Altman et al., 2018). Reducing the incidence of delirium has even been found to decrease the number of patient falls (Ferguson et al., 2018). Involving willing family members of ICU patients in delirium-prevention measures and decreasing the frequency of neurological assessments have been offered as feasible interventions to reduce delirium in the ICU (McLaughlin et al., 2018; Smithburger et al., 2017). Guidelines and protocols supporting protected rest periods in ICUs are ideal (Li et al., 2011). Each of the aforementioned studies looked at different interventions regarding their effect on delirium, and all acknowledged that lack of sleep is known to exacerbate it. This evidence-based practice change project implemented guidelines that promote noise and light control, and the 
reduction of non-emergent interventions during "quiet time" to maintain circadian rhythm and reduce sleep deprivation and fragmentation, thereby reducing ICU-associated delirium.

\section{Significance of the Practice Problem}

The effects of protected sleep in the ICU may positively impact patients' outcomes by reducing delirium, LOS, and overall mortality (Irwin et al., 2016). The impact on the healthcare system may be profound because shortened LOS reduces the financial cost of recovery to the patient and the healthcare system. Families may also be positively impacted because they may be able to avoid the distress of seeing their loved ones in a state of delirium and confusion.

The financial burden of treating delirium in the United States is a staggering \$164 billion per year (Ferguson et al., 2018). In 2010 the average daily cost of an ICU stay was $\$ 4,300$ (Society of Critical Care Medicine, n.d.). More recent data suggested an initial-day ICU expense of $\$ 10,794$, which levels out to $\$ 3,968$ by day 3, depending on whether the patient requires mechanical ventilation (Cunningham et al., 2020). Longer ICU LOS increases morbidity and mortality (Altman et al., 2018). There is a reliable association between sleep fragmentation and delirium (Irwin et al., 2016; Patel et al., 2014). One study, conducted in a neurological ICU, suggested the de-escalation of neuro-status checks after a patient has been there for more than 48 hours. The authors acknowledge that although the frequency of neurological assessment is initially done to avoid missing a key finding, after a certain time, it causes more harm than good (McLaughlin et al., 2018). The strength of this recommended practice change comes from the algorithm wherein sleep hygiene is a key recommendation in the diagnosis of ICU delirium, based on patient-oriented evidence and not opinion, consensus, or usual practice (Ebell et al., 2004). 
The hospital where this project was implemented has not historically collected data specifically related to ICU delirium, but they do closely monitor LOS. Compared with national benchmarks, this facility has higher than expected LOS for several diagnoses. The Strategic Analytics for Improvement and Learning (SAIL) Value Model is a system used within the organization for data collection and quality improvement project analysis (SAIL, n.d.).

\section{PICOT Question}

This project sought to answer a practice question using the PICOT format, which means that for a certain population $(\mathrm{P})$, the implementation of an intervention (I), compared with not doing the intervention $(\mathrm{C})$, leads to an outcome $(\mathrm{O})$ over time $(\mathrm{T})$. For this project, the following PICOT question was addressed: For patients in an adult ICU, does using a nurse-initiated, nonpharmacological sleep-enhancement protocol, versus no sleep-enhancement protocol, reduce the incidence of ICU-delirium over 2 months?

This hospital is unique in that there are two divisions, Uptown and Downtown, separated by approximately 4 miles. Uptown houses nursing homes, rehabilitation units, and many outpatient clinics. Downtown houses the Spinal Cord Injury Unit (SCIU), three acute care units, and a Critical Care Unit (CCU), which comprises the Intensive Care Unit (ICU) and the Stepdown Unit (SDU).

A single team governs both facilities and reports to the organization's Integrated Service Network (VISN). Local leadership is led by a facility director who has a chief of medicine and a chief of nursing as direct reports, supported by many service line chiefs, then the unit managers and assistant managers.

In order to ensure consistent application of the protocol, bedside nurses and physicians were trained by PowerPoint-supported inservices regarding the detriment of delirium and the 
importance of protected rest periods. Staff members were post-tested on the purpose of the project and rationale in the hopes of gaining buy-in as to the importance of it. Once all were inserviced on the sleep enhancement protocol a firm start date was determined. Ancillary departments were notified of the practice changes, so they were able to adapt their workflow as needed. All CCU patients received the intervention, but those that were admitted for fewer than 24 hours or were comatose at the time of admission have been excluded from data collection. Because chemical paralysis would preclude an accurate assessment of delirium presence, those patients have also been excluded from the data.

\section{Evidence-Based Practice Framework and Change Theory}

Using a three-step process called PET (practice question, evidence, and translation), the Johns Hopkins Nursing Evidence-Based Practice (JHNEBP) model framed the quality improvement initiative for this project. Each of the PET steps are supported by sub-steps intended to facilitate project success. For instance, in the practice question phase, a problem was identified, and the team recruited. In the evidence phase, literature supporting the practice change was synthesized and a recommendation for change was made. In the translation phase, the action plan was created and implemented, then evaluated and reported. The goal of this model was to expeditiously apply research into bedside practice (Dang \& Dearholt, 2017). The JHNEBP model was the best fit for this project because it is an uncomplicated model for implementation of best practice (Schaffer et al., 2013). The PET process (see Appendix A) details the steps of implementation. See Appendix B for permission letter to use the PET tool.

The theory that best fit this practice change is Lewin's Change Theory, which has three phases: unfreezing, movement, and refreezing (Hussain, 2018; Lewin, 1947). This process is prevalent in practice literature (Stouten et al., 2018). The initial phase, unfreezing, is intended to 
allow time to develop a vision and a plan for change. Unfreezing will identify the problem and possible cause. Garnering support from stakeholders in this phase, or earlier, bolsters the chance of success for the project (Hussain, 2018). The second phase involves the movement of applying the change. In this case, movement is where the protocol implementation happens, and measurement begins and is evaluated in terms of improvement (Lewin, 1947, as cited in Hussain, 2018). Refreezing, the final phase, entails making the change or new processes permanent by solidifying it in the organization (Lewin, 1947, as cited in Hussain, 2018; Stouten et al., 2018). Lewin's Change Model applied to this project because it spoke to the simplicity of the process of movement while also acknowledging the difficulty of it. Unless nurses understood the negative impact of the status-quo, and were included in the process of change, they may have abandoned the project or, worse, never supported it at all.

\section{Evidence Search Strategy}

A review of literature was conducted using the following databases: The University of St. Augustine for Health Sciences' Library, EBSCO, Cumulative Index to Nursing and Allied Health (CINAHL), MEDLINE, Google Scholar, PubMed, and Ovid. The basic search began, unfiltered, with "non-pharmacologic sleep protection in the ICU." This search yielded 1605 results over several decades. Initial exclusions included articles that were not written in English, not immediately available as a full document, or that were pediatric based. Subsequent exclusions included articles focused on delirium in patients with head injuries, brain tumors, or other pre-existing neurological disorders. Applying filters using the Boolean operators, including "AND" and "OR" to form relevant statements that included prevention of delirium, reduction of delirium, non-pharmacologic, nursing protocols, and ICU reduced the results to 201 citations and articles. The following Medical Subject Headings ("delirium," "delirium AND nurses," "nurses 
AND initiated," "initiated AND nonpharmacologic") were added to narrow the selection of articles Comparative words ("reduction" and "intervention") were also included. This reduced the number of articles to 68 . The time frame was limited to 2013-2020, which brought the results to 16 articles. See Table 1 for complete inclusion and exclusion criteria.

\section{Table 1}

\section{Article Selection Criteria}

\begin{tabular}{|l|l|}
\hline \multicolumn{1}{|c|}{ Inclusion Criteria Applied } & \multicolumn{1}{c|}{ Exclusion Criteria Applied } \\
\hline Full-text articles & Unpublished article or report \\
\hline Within date range of 2013 to 2020 & Publication with no MeSH indexing \\
\hline Qualitative and Quantitative study method & Publications outside date range \\
\hline Includes ICU delirium & Articles without author or unclear \\
\hline $\begin{array}{l}\text { Includes nonpharmacologic order set / } \\
\text { protocol }\end{array}$ & Abstracts or full-text unavailable \\
\hline Includes nurse-initiated orders / protocols & Pediatric \\
\hline & Pharmacotherapeutic interventions \\
\hline
\end{tabular}

\section{Evidence Search Results}

The Strength of Recommendation Taxonomy (SORT) grading tool was used to categorize recommendations in the clinical review articles (Ebell et al., 2004). Articles represented a variety of methods and designs including prospective-retrospective, quasiexperimental, randomized, systematic review, and descriptive. The qualifying articles were included based on the JHNEBP grading from levels I to V for project use. Figure 1, the Preferred Reporting Items for Systematic Reviews and Meta-Analysis (PRISMA), illustrates the summary of results. 


\section{Themes with Practice Recommendations}

The literature was assessed and synthesized for common themes (see Appendices $\mathrm{C}$ and D). Reliable evidence was found supporting nurse-initiated, nonpharmacologic promotion of sleep for the purpose of reducing or preventing delirium. The Society of Critical Care Medicine (SCCM) stated in its latest revision of the Clinical Practice Guidelines for the Management of Pain, Agitation, Delirium and Immobility (PADI): "We recommend promoting sleep in adult ICU patients by optimizing patients' environments, using strategies to control light and noise, clustering patient care activities, and decreasing stimuli at night to protect patients' sleep cycles" (Barr et al., 2013, p. 266). To that end, each of the following themes supports a quality change initiative.

\section{Intentional Quiet Time}

Intentional quiet time includes several simple, but often overlooked interventions like noise reduction by turning off televisions, closing doors when safe and appropriate to do so, eliminating overhead pages, and turning down nonessential monitor volume (Faraklas, et al., 2013; Kram et al., 2015; Patel et al., 2014). McLaughlin et al. (2018) suggested that for the nonneurologic patient, serial neurologic checks may be unnecessary once baseline is established.

\section{Clustered Care}

Avoiding fragmentation of sleep included care clustering, where disruptions for the resting patient are limited (Kram et al., 2015; Rivosecchi, et al., 2016). An example would be doing med pass, lab work, and chest x-ray all in the same interaction instead of three separate interactions. This required intentional coordination with ancillary departments. 


\section{Environmental Manipulation}

Dimming of overhead lights at night and during quiet time can promote patients' natural circadian rhythm (Faraklas et al., 2013; Kamdar et al., 2014; Patel et al., 2014; Smith \& Grami, 2017). Wake cycles are enhanced by opening blinds or turning on overhead lights, avoiding caffeine, and limiting excessive daytime naps (Faraklas et al., 2013; Kram et al., 2015; Patel et al., 2014). Birge and Aydin (2017) emphasized comfortable positioning to enhance sleep.

\section{Reorientation}

Constant reorientation measures included updating whiteboards, clocks, and calendars (Birge \& Aydin, 2017; Faraklas, 2013). Consistent presence of family members may help mitigate the incidence and duration of delirium in the ICU (Smithburger et al., 2017).

\section{Improved Outcomes}

Evidence from the literature revealed improved outcomes when sleep protocols were implemented (Avendaño-Céspedes et al., 2016; Kamdar et al., 2014, Kram et al., 2015; Martinez et al., 2017; Patel et al., 2014; Rivosecchi et al., 2016; Smith \& Grami, 2017). The use of standardized, reliable assessment tools (CAM-ICU or ICDSC) strengthened the validity of sleep bundles to reduce ICU delirium (Faraklas et al., 2013; Kamdar et al., 2014; Kram et al., 2015; Patel et al., 2014; Rivosecchi et al., 2016; Smith \& Grami, 2017).

\section{Practice Recommendations}

The specific aim of this project was to reduce the incidence of delirium in the ICU. Evidence from the literature suggested a direct link between improving sleep and reducing delirium (Irwin et al., 2016; Li et al., 2011; Patel et al., 2014). Some suggestions for improved sleep were utilizing protocolized care bundles that include clustering of care to provide 
intentional rest periods, avoiding benzodiazepines, manipulating the physical environment, and reorienting the patient frequently (Farklas et al., 2013; Irwin et al., 2016; Li et al., 2011).

Delirium causes increased LOS and mortality and reduced functional ability for up to a year after discharge (Altman et al., 2018; Faraklas et al., 2013; Ferguson et al., 2018). Evidence further suggested that utilizing a nurse-initiated sleep enhancement protocol in the ICU may have a positive financial impact to the organization, since the average increase in cost of ICU care once delirium develops is 39\% (Vasilevskis et al., 2018). This project sought to follow best practices to reduce delirium by nonpharmacologically reducing fragmentation of sleep; the cost to implement was negligible. The greatest investment was that of time: on the front-end training nurses about the project and reinforcing the standard assessment tools; on the back end the analysis and dissemination of data. The organization already had a comprehensive training manual for using the CAM-ICU which was embedded into one of the computer-based training platforms (Elsevier) and tracked for compliance (Boehm et al., 2016). The practice change recommendation was to check each shift for ICU-associated delirium using an evidence-based assessment tool, the CAM-ICU (Boesen et al., 2015; Li et al., 2011; Patel, et al., 2014). Nurses were uniquely positioned to assess for and recognize delirium, since they spend much of their work time at the bedside (Pessoa et al., 2019). Expected outcomes included the implementation of a facility-approved, nurse-initiated protocol (NIP) which resulted in a slightly reduced rate of delirium in this ICU population.

\section{Setting, Stakeholders, and Systems Change}

\section{Project Setting}

This project took place in the 20-bed Critical Care Unit (CCU) of a hospital in eastern Georgia. Ten CCU beds are designated as Intensive Care Unit (ICU) beds and ten are Stepdown Unit (SDU) beds. The pre-pandemic average daily hospital census was 78-85 \% total capacity, 
with occasional community diversions when the unit was at capacity (Hospital website, n.d.). On the ICU side, nurse to patient ratio was 1:2 except for high-acuity procedures (e.g., continuous dialysis, targeted temperature management, or balloon pump). On the SDU side the nurse-topatient ratio was 1:3. Ever-present in the CCU is tele-ICU, which represents $24 / 7$ nursing coverage, and board-certified physician coverage during off-tour hours when attending physicians were not in-house. Resident physicians were always in the facility, but tele-ICU serves as a second set of eyes for nurses and providers. Other support staff necessary for the project's success included pharmacists, respiratory therapists, nurses' aides, students, and unit clerks.

\section{Organizational Structure}

The hospital where this project was implemented is a two-division facility with three affiliated community-based outreach centers. The downtown division houses the CCU, as well as 156 acute care and Spinal Cord Injury Unit (SCIU) beds. It also contains an invasive cardiology suite with two cardiac catheterization laboratories and a fully operational 16-bed Emergency Department (ED).

\section{Organizational Culture}

Organizational core values of this hospital system are Integrity, Commitment, Advocacy, Respect, and Excellence (I-CARE) which encapsulates the vision and supports the organization's mission to fulfill President Lincoln's (1865) promise "to care for him who shall have borne the battle, and for his widow, and his orphan" (p. 4). The organization is led by the director, the associate director, the assistant director, associate director of patient care services, and the medical director. This team is known locally as "The Pentad." The next tier of leadership includes service line chiefs, followed by managers, and then the front-line care staff. 


\section{Organizational Need}

At the outset of this project, there were no standard operating procedures or protocols for CCU staff to follow or fall back on when delirium was suspected. The same was true at the end of the project. Delirium occurrence in this ICU follows national trends with as much as $80 \%$ of the patients experiencing some level of delirium during their stay (M. Stipsits, Nurse Manager, personal communication, December 2018). Therefore, the recommendation for improvement remains the implementation of a nurse-driven, non-pharmacologic sleep protocol for the purpose of avoiding the development of delirium whenever possible.

\section{Stakeholders}

Project stakeholders included the aforementioned pentad, nursing and physician leadership, tele-ICU, ancillary department members, and patients and their family members in the CCU. The medical director, nurse manager, and assistant nurse manager are key stakeholders, alongside front-line nursing staff. Given the interdisciplinary team approach of CCU from physician providers, nursing staff, and supporting ancillary departments (including but not limited to the laboratory, chaplaincy, radiology, physical therapy, occupational therapy, speech therapy, nutrition, hospital education, and wound care consultants) this project was set to become a successful practice improvement initiative. And then a pandemic struck.

\section{Strengths, Weaknesses, Opportunities, and Threat Analysis}

A strengths, weaknesses, opportunities, and threats (SWOT) analysis was done to assess and mitigate potential barriers to project success. See Figure 2 for a visual representation of the SWOT. Strengths included the support of upper leadership, CCU teamwork, and the potential for increased patient and family satisfaction. Weaknesses included the newness of the CCU 
leadership team. The medical director had been on board about 1 year at the time the project gained facility approval, and the nurse manager had been there for a shorter period of time. He is the 11th nurse manager in 8 years. There was a new assistant nurse manager (hired September 2020), and no clinical nurse leader. The CCU educator transferred from a related facility in May 2020. Opportunities included the standardization of delirium care and prevention. Since this protocol was nurse-driven, nursing staff experienced autonomy in recognition and implementation of best practices. Threats included resistance to change, non-compliance, and the incredible ingenuity of nurses to invent "workarounds" as a result. In-servicing was planned to help lessen these weaknesses and threats. The biggest threat was one that could not have been anticipated, which was the COVID-19 global pandemic. This worldwide threat changed nearly everything about critical care delivery.

\section{Figure 2}

SWOT Analysis

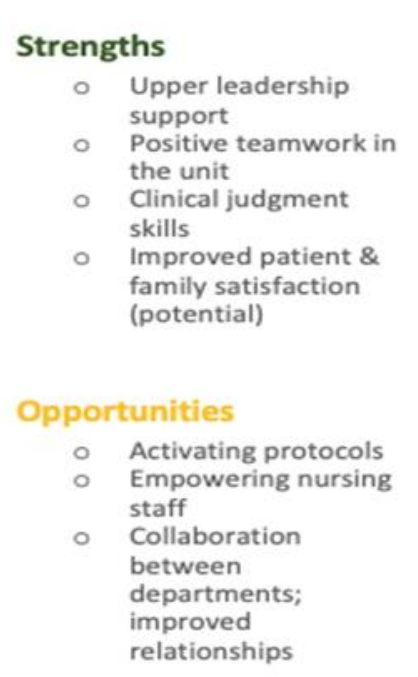

SWOT Analysis

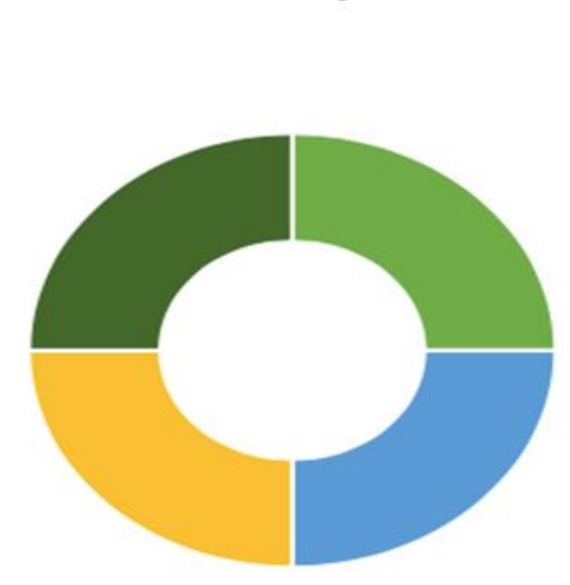

Weaknesses

- New leadershipstill orienting

Nursing \& Provider staffing shortages

- Subjectivity in clinical assessments

\section{Threats}

- Resistance to change

- Apathy by Providers

- Staff noncompliance and work-arounds 


\section{Implementation Plan with Timeline and Budget}

\section{Mission, Vision, and Objectives}

Mission statements convey the purpose of businesses while vision statements describe a project's anticipated goals (Meyer, 2019). The mission statement of this facility is to serve our patients with care, compassion, and commitment (Facility Volunteer Handbook, n.d.). The vision of this project was to use nurses' intervention via a standardized protocol to affect a reduction in incidence of delirium in the CCU over 2 months. Anticipated anecdotal benefits were shortened overall LOS and earlier liberation from mechanical ventilation for patients on life support. At implementation, all CCU nurses understood the sleep enhancement protocol, were able to articulate its benefits, and properly apply it.

\section{Short- and Long-term Objectives of the Project}

Short-term goals for this project included obtaining stakeholder support and implementation through training and allowing time for questions and answers, which included reference to similar successful projects. Within 5 days of initial training, there was $>90 \%$ use of the protocol. This was verified by a $100 \%$ audit per the project manager.

The long-term goal of this project was to reduce delirium in the CCU. Sustained use of the sleep enhancement protocol was evidenced by the adoption of it into standard practice in the CCU. Ongoing clinical training will be accomplished with annual assessment of competence using the CAM-ICU tool. To sustain stakeholder buy-in, quarterly status reports of delirium rates will be provided to the staff so they can continue see the direct results of their efforts.

\section{Risks and Unintended Consequences of the Project}


Mitigating pitfalls and barriers is crucial to the success of this or any future project to be implemented in the CCU. The primary barrier to this project was the COVID-19 pandemic and its effect on patient flow, treatment, and outcomes. This hospital experienced a second wave of the pandemic in November 2020 which resulted in the majority of patients being intubated and sedated, with many being placed in the prone position for maximum oxygenation. Proning requires chemical paralyzation, which means that those patients were unable to participate in delirium assessment. This factor alone reduced the sample size markedly.

Nursing staff who completed the pre-implementation training early and demonstrated competence in the use of the assessment tool (CAM-ICU) served as subject matter experts. These experts helped encourage their peers who either had not done the training or did not initially buy in to the protocol. Data, essential to understanding intervention efficacy, was collected twice weekly, and analyzed weekly. Unintended negative effects were mitigated via regular communication with the CCU staff throughout the length of the project. While it was known that a large data pool would not be realized because of the pandemic, the project manager proceeded with the project and communicated as originally planned.

\section{Project Plan (Method)}

For this project, a pre- and post- assessment was done to compare CAM-ICU scores in CCU patients before and after implementing the nurse-initiated sleep enhancement protocol. A chart review using the Computerized Patient Record System (CPRS) was done to compare CAM-ICU scores at baseline (pre-implementation) and post-implementation of the sleep enhancement protocol. Total number of patients with positive CAM-ICU was assessed in retrospective patient populations during the 30 days before implementation and compared to those receiving the nurse-driven protocols over a period of 30 days. The goal was to reduce the 
incidence of ICU-delirium in that time frame. As evidenced by assessing the number of delirious patients divided by the total number of patients in the $\mathrm{CCU}$ on a random day, the initial rate of delirium was $60-70 \%$. Lewin's Change Theory was the framework for this project alongside the JHNEBP model for implementing change.

\section{Project Steps}

Leadership in CCU and the Hospital Education Department supported this project to decrease delirium in the unit and see it as an important evidence-based practice change initiative for the organization overall. Implementation of this project began with the planning phase followed by training by inservice for the nursing and provider staff regarding delirium as an effect of sleep fragmentation. Use of the CAM-ICU tool was reinforced using an alreadypublished, system-wide how-to manual embedded in, and tracked by, one of the computer-based training systems of the facility. Staff members were able to download it to their cloud drive for reference. All training was done using the Donna Wright method, which emphasized lateral training with three main components of understanding: a) competencies are collaborative, b) the learner is the central focus of competency evaluation, and c) leaders create a dual-focused (employee, organization) culture of success (Wright, 2005).

Implementation occurred in the following order:

1. Planning for the implementation of an evidence-based, nurse-initiated sleep enhancement protocol was formally approved by the CCU medical director, nurse manager, and DNP preceptor.

2. Staff training was done (utilizing Donna Wright method) on the detriment of delirium, use of the CAM-ICU tool, and sleep enhancement protocol.

3. Dry-run evaluations were completed prior to go-live. 
4. Implemented the sleep enhancement protocol in November 2020.

5. Periodic data collection and PDSA cycling were done.

6. Data analysis was conducted using Intellectus, and MS-Excel spreadsheets.

7. Dissemination of project results.

A detailed timeline of the project is included (see Appendix E) and represents the schedule for this quality improvement process.

\section{Budget and Resource Needs}

Training classes on delirium, CAM-ICU, and sleep enhancement protocols were provided by the project manager, founded on emailed PowerPoint presentation, rounding inservices, and wall posters. The information was reinforced by super-trainers. Initial delirium and CAM-ICU training took place by email blast of the CAM-ICU Training Manual which was used for crossreferencing throughout the project. The manual is a preexisting system-wide document accessible to all facility staff. Protocol training was in the form of 15-30-minute in-services with time following for questions and concerns. Thirty-minute training sessions for $40 \mathrm{CCU}$ nurses either before or after their tour-of-duty cost the facility approximately $\$ 700$ given that the average hourly salary for the CCU nurses is $\$ 35$. Approval for this expense came from the chief financial officer and the nursing chief of medicine. Once training took place, protocol implementation became part of the normal workflow of the bedside nursing staff, and no additional equipment or supplies were needed for implementation.

The benefit of reducing fragmented sleep in the CCU was intended to be less delirium, with secondary benefits being shorter LOS and improved overall outcomes. The pandemic impacted this project significantly, however, data from 2010 indicated the average cost-per-day of an ICU stay is $\$ 4300$, depending on acuity and use of resources (Critical Care Statistics, n.d.). 
This figure represented a $61 \%$ increase in cost from 2000 data, so the current ICU-cost-per-day is likely much higher now (Critical Care Statistics, n.d.). A table representing the project budget (Appendix F) is included.

\section{Evaluation}

The project evaluation tool (see Appendix G) facilitated measurement of changes in the rate of delirium in the $\mathrm{CCU}$ after 4 weeks of the sleep enhancement protocol implementation. An analysis of pre- and post- sleep enhancement protocol implementation has determined only a slight reduction in delirious patients in $\mathrm{CCU}$ after the 4-week timeline. EMR review included all non- proned or paralyzed patients admitted to the CCU during the 4-week total review.

CAM-ICU (Appendix H) is the defined measurement tool to assess for delirium for this project. Richmond Agitation Sedate Scale (RASS) (see Appendix I) assesses for sedation and is completed with the CAM-ICU to ensure patients are not too sedated to accurately assess for delirium; it is not completed on alert patients. Preventing delirium can positively impact overall patient outcomes (Devlin et al., 2018). Based on this knowledge, practice changes from implementing a sleep enhancement protocol provided: a). autonomy for nursing staff to intervene with protocolized measures to avoid delirium b). empowerment of nursing staff to use their assessment findings to apply a new protocol c). pride of the nursing staff at trying to reduce delirium and its associated sequelae of negative events that often accompany it.

\section{Team Specifics}

The team involved in the work of this project consisted of the project manager, $\mathrm{CCU}$ nursing leadership, and the bedside nursing staff. Support staff included the resident and attending physician group, the pharmacy and other ancillary departments (for medication and therapy scheduling purposes). Family members and other surrogates would have been recruited 
to help minimize the incidence of ICU delirium by engaging them in protecting the sleep of their loved ones, but at the time of this project all visitations were on hold as a result of COVID-19 safety recommendations. Families are largely willing to be involved in helping to prevent delirium (Smithburger et al., 2017) so the fact that they could not be included was disappointing. For nurses, the non-COVID care they delivered did not change, only the timing of it did. The effort of the team was supported by stakeholders, and the project will be revisited house-wide after the pandemic in hopes of realizing greater benefit for patients at every level of acuity.

\section{Inclusion and Exclusion Criteria}

Initial inclusion criteria for participants in this project were as follows: a) 18 years of age, b) conscious, as indicated by any RASS other than -4 or -5 , c) non-delirious as indicated by a negative CAM-ICU score, d). able to communicate in English, e) length of CCU stay >24 hours. Exclusion criteria for participation were: a) age younger than 18 years, (b) exhibition of primary dementia, (c) unconscious as indicated by a RASS score of $-4 /-5$, or (d) refusal to participate. Ultimately, the chemically paralyzed and proned patients were also excluded. Also, as a result of the pandemic, CCU had to be expanded into the adjoining 8-bed, open- bay Post Anesthesia Care Unit. The only partition between beds were curtains, and there was no buffer for noise or light in that area. Those patients could not be included in the project because there was no way to alter the environment for one without altering it for all.

\section{Data Collection Details}

Throughout the project, all patients meeting the criteria for the sleep enhancement protocol implementation were tracked and trended by the project manager/graduate student. A pre-implementation rate of delirium was determined by calculating the rate for 30 days prior to implementation to provide a baseline measurement. After implementation, for 30 days, the rate 
was calculated again to ascertain change. The outcome was a slight reduction in delirium for patients in the CCU.

The collection phase answered the measures associated with the PICOT. Outcome measures that were collected include a reduction in positive CAM-ICU scores and, anecdotally, LOS in the CCU. (LOS is calculated by subtracting the date of admission from the date of discharge.)

\section{Types of Measures}

For any quality improvement project, measurements validate the project results (Institute for Healthcare Improvement [IHI], 2020). The measures chosen for studying processes and outcomes of the intervention are the CAM-ICU and the RASS, which are valid and reliable delirium assessment tools recommended by the SCCM in its 2013 Pain, Agitation, and Delirium PADI guidelines (see Appendices $\mathrm{H}$ and I). The independent variable of this project is the sleep enhancement protocol implementation. The dependent variable is the rate of delirium. Table 2 includes details for each category of measure for the project with the type of statistical test to be used for each measure.

\section{Table 2}

Measures, Goals, and Statistical Analysis

\begin{tabular}{|c|c|c|c|c|}
\hline MEASURE & CATEGORY & DEFINITION & GOAL & $\begin{array}{l}\text { STATISTICAL } \\
\text { TEST/ DATA } \\
\text { TYPE }\end{array}$ \\
\hline CAM-ICU & Outcome & $\begin{array}{l}\text { Negative score }=\text { no delirium present. } \\
\text { Current rate is } 80 \% \text { positive CAM-ICU }\end{array}$ & $\leq 80 \%$ & $\begin{array}{l}\text { Continuous data/ } \\
\text { unpaired t-test }\end{array}$ \\
\hline LOS in CCU & Outcome & $\begin{array}{l}\text { Length of time admission to discharge or } \\
\text { transfer from CCU }\end{array}$ & $\leq 3$ days & $\begin{array}{l}\text { Ratio } \\
\text { data/measures of } \\
\text { frequency }\end{array}$ \\
\hline $\begin{array}{l}\text { Number of staff } \\
\text { to complete SEP } \\
\text { training }\end{array}$ & Process & $\begin{array}{l}\text { Number of clinical staff to successfully } \\
\text { complete SEP training. Numerator is } \\
\text { number of staff completing training \& } \\
\text { denominator is total number of staff. }\end{array}$ & & $\begin{array}{l}\text { Categorical data / } \\
\mathrm{X}^{2}\end{array}$ \\
\hline Cost of Training & Financial & $\begin{array}{l}\text { Total number of clinical staff multiplied by } \\
\text { hourly rate x } 1 \text { hour. }\end{array}$ & $\begin{array}{l}\$ 700.00 \text { with } \\
\text { average hourly } \\
\text { rate of } \$ 35.00\end{array}$ & $\begin{array}{l}\text { This figure is also } \\
\text { represented in } \\
\text { Appendix F }\end{array}$ \\
\hline
\end{tabular}




\section{Outcome Measures}

The primary outcome measure for this project was reduced incidence of delirium pre- and post-implementation. Secondary outcome measure was CCU LOS. Average LOS was calculated by dividing the total days of ICU stay for all patients included in the data collection pool by the number of discharges. There was a pre- and post- intervention pool. A smaller number in the post-implementation data pool would have indicated a shorter ICU LOS, but this did not occur. At staff meetings and daily huddles, the nurse manager and project manager provided updates, opportunities for improvement, and progress related to the initiative.

\section{Process Measures}

Process measures are defined as the steps that lead a project to its outcome (IHI, 2020). The process measure for staff completion of the sleep enhancement protocol inservice was done by assessing the percentage of staff that attended inservices before the roll-out date. The goal was $90 \%$. Proper use of the CAM-ICU was reinforced to staff nurses in the ICU and evaluated using occasional direct observation and random chart review. The Donna Wright model of competency assessment helped to identify champion staff that were able to reinforce and support the use of the protocol during the implementation phase and beyond (Wright, 2005).

\section{Balancing Measures}

A balancing measure asks whether changes designed to improve one part of a system causes new problems in other parts of the system (IHI, 2020). The balancing measure for this project was the percentage of the staff that find satisfaction with the use of the sleep enhancement protocol. The project manager assessed staff satisfaction by way of random interviews following the completion of the project. The question asked was "Do you feel as though the Sleep Enhancement Protocol was helpful for our patients?" Staff members were 
invited to provide specific feedback in an email reply, but it was not required. All of the 25 staff who were interviewed saw value in the protocol and agreed that it will be an easy intervention to provide in the future.

\section{Financial Measures}

The direct and indirect expenses of a project are indicated as financial measures (IHI, 2020). They helped to determine any monetary requirements for the project and were approved by the organization before implementation. For the purpose of this project, financial measures (see Appendix F) include the cost of training the clinical staff in the form of a half-hour inservice on the detriment of delirium and reinforcement of the proper use of the CAM-ICU tool. The PowerPoint presentation used for in-servicing is included (see Appendix $\mathrm{J}$ ), and the protocol is embedded in it (see Appendix K).

\section{Validity and Reliability}

Validity confirms that the data results represent the proposed measure for the project (reduction of delirium) and reliability demonstrates stability and consistency over time (Sylvia \& Terhaar, 2018). The project manager, alongside the statistics team, both played an active role in data collection, evaluation, and chart reviews. The RASS (see Appendix I) is a 10- point scale for measuring sedation, with four grades of anxiety or agitation above 0 ("restless" to "combative"), and five levels of sedation below zero ("drowsy" to "unarousable") (Sesser et al., 2002). A score of zero indicates a calm and alert state. A score $>-3$ means the patient can be CAM-ICU assessed. A score of -4 or -5 means the patient is too sedate to assess for delirium. This data will be measured both pre- and post-intervention. The CAM-ICU (see Appendix H) is the most commonly used instrument for diagnosing delirium (Devlin et al., 2018; Ely et al., 2002). It takes about 2 minutes to complete and can be used with both verbal and non-verbal 
patients (Ely et al., 2002). Typically, RASS and CAM-ICU are used together: the former to assess sedation and latter to assess delirium. The CAM-ICU is well-validated and showed highinterrater reliability $(\mathrm{k}=0.94, \mathrm{p}<0.001)$ (Devlin et al., 2018; Ely et al., 2002). The CAM-ICU tool included four parts, which assess in order: mental status changes, inattention, disorganized thinking, and level of consciousness (Ely et al., 2002). Patients were either positive, negative, or unable to be scored. Deficits in features judgement or attentiveness indicate that the patient was delirious (Ely et al., 2002). These have been measured pre- and post- implementation of the sleep enhancement protocol.

\section{Data Analysis}

The data collection tool (see Appendix F) is a descriptive table and provides each data collection point for the project: the date, numeric patient code, admission and discharge dates, LOS, CAM-ICU scores for each shift, RASS score, protocol initiation time, whether there were any interruptions, and a block for extraneous notes.

Data collection originated from CPRS, a reliable and valid EMR utilized by all medical centers in this healthcare system. Descriptive statistics were used to measure the frequency of delirium (Sylvia \& Terhaar, 2018). Random chart audits were completed for the sleep enhancement protocol usage among the nursing staff with a goal of $\geq 90 \%$ which was the measurement of compliance for the hospital. Pre-implementation data was collected using chart audits during the four weeks prior to starting the protocol. All qualified CCU patient charts were reviewed and CAM-ICU scores were collected daily during the post-implementation phase. Table 2 provides a complete explanation of the measures of frequency, central tendency, and inferential statistics that were utilized. 


\section{Project Results}

Data were collected by the project manager, according to timeline and plan. It was collected on the attached data collection tool, then shredded after being imported into Excel. A security chip-accessed federal computer was used, which is in an interior, locked office. Data were evaluated in collaboration with a statistician at Intellectus, using their proprietary software.

\section{Chi-square Test of Independence}

A Chi-square Test of Independence was conducted to examine whether Time and CAM_ICU were independent. There were 2 levels in Time: Pretest and Posttest. There were 2 levels in CAM_ICU: Yes and No.

\section{Assumptions}

The assumption of adequate cell size was assessed, which required all cells to have expected values greater than zero and $80 \%$ of cells to have expected values of at least five (McHugh, 2013). All cells had expected values greater than zero, indicating the first condition was met. A total of $50.00 \%$ of the cells had expected frequencies of at least five, indicating the second condition was violated. When the assumptions of the Chi-square test are violated, Fisher's exact test can be used to produce more reliable results with small sample sizes. Logit models such as binary logistic regression can be used for larger sample sizes.

\section{Chi-square Results}

The results of the Chi-square test were not significant based on an alpha value of 0.05 , $\chi 2(1)=0.95, p=0.329$, suggesting that Time and CAM_ICU could be independent of one another. This implied that the observed frequencies were not significantly different than the expected frequencies. Four out of 10 patients exhibited signs of delirium pre-intervention, and only two of 10 showed signs of delirium post-intervention. While this looks like a reduction of 
$50 \%$, it is not statistically significant due to the small sample sizes both before and after the sleep enhancement intervention. Table 3 presents the results of the Chi-square test.

Table 3

Chi-square Test Results of Observed and Expected Frequencies

\begin{tabular}{lcrrrr}
\hline & \multicolumn{2}{c}{ CAM_ICU } & & & \\
\cline { 2 - 5 } Time & Yes & No & $\chi^{2}$ & $d f$ & $p$ \\
\hline Pretest & $4[3.00]$ & $6[7.00]$ & 0.95 & 1 & .329 \\
Posttest & $2[3.00]$ & $8[7.00]$ & & & \\
\hline
\end{tabular}

Note. Values formatted as Observed[Expected].

Two-Tailed Independent Samples t-Test

A two-tailed independent samples t-test was conducted to examine whether the mean of LOS-in-days was significantly different between the pre-test and post-test categories of time.

\section{Assumptions}

Shapiro-Wilk tests were conducted to determine whether LOS-in-days could have been produced by a normal distribution for each category of Time (Razali \& Wah, 2011). The result of the Shapiro-Wilk test for LOS-in-days in the pretest category was significant based on an alpha value of $0.05, \mathrm{~W}=0.77, \mathrm{p}=0.006$. This result suggested that LOS-in-days in the pre-test category is unlikely to have been produced by a normal distribution. The result of the ShapiroWilk test for LOS-in-days in the post-test category was significant based on an alpha value of $0.05, \mathrm{~W}=0.82, \mathrm{p}=0.022$. This result suggested that LOS-in-days in the post-test category is unlikely to have been produced by a normal distribution. The Shapiro-Wilk test was significant for both the pre-test and post-test categories of time, indicating the normality assumption is violated.

Levene's test was conducted to assess whether the variance of LOS-in-days was equal between the categories of time. The result of Levene's test for LOS-in-days was not significant based on an alpha value of $0.05, F(1,18)=0.21, p=0.653$. This result suggests it is possible that 
the variance of LOS-in-days is equal for each category of time, indicating the assumption of homogeneity of variance was met.

\section{T-test Results}

The result of the two-tailed independent samples t-test was not significant based on an alpha value of $0.05, \mathrm{t}(18)=0.01, \mathrm{p}=0.993$, indicating the null hypothesis cannot be rejected. This finding suggested the mean of LOS-in-days was not significantly different between the pretest and post-test categories of time, and the sleep enhancement protocol did not have any impact on LOS. The results are presented in Table 4. A bar plot of the means is presented in Figure 3.

\section{Table 4}

Two-Tailed Independent Samples t-Test for LOS-in-days by Time

\begin{tabular}{ccccccccc}
\hline & \multicolumn{3}{c}{ Pretest } & \multicolumn{3}{c}{ Posttest } & & \\
\cline { 2 - 5 } Variable & $M$ & $S D$ & $M$ & $S D$ & $t$ & $p$ & $d$ \\
\hline LOS-in-days & 13.05 & 14.52 & 13.00 & 11.93 & 0.01 & .993 & 0.00 \\
\hline
\end{tabular}

Note. $\mathrm{N}=20$. Degrees of Freedom for the $t$-statistic $=18 . d$ represents Cohen's $d$.

\section{Figure 3}

The Mean of LOS-In-Days by Levels of Time

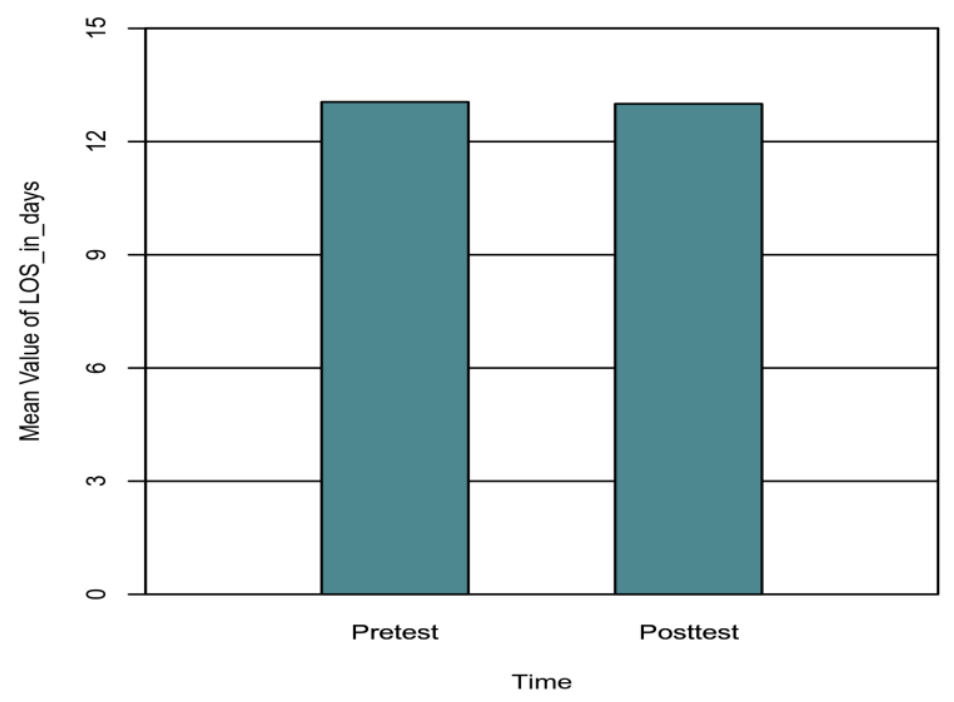




\section{Missing Data and Storage}

Data regarding the interventions of the project have been thoroughly documented and followed daily through the entirety of the project timeline. When noncompliance with the assessment tools threatened the project, staff members were reminded in person to complete them. All relevant information has been added to the database at twice weekly intervals in the form of an Excel spreadsheet. The need for accurate data and consistency with CAM-ICU assessment and the sleep enhancement protocol implementation was reinforced to the project team members at huddle twice weekly. Data was obtained from the electronic health record and stored on a computer physically located inside an interior office with two locked doors and accessible only with a key card and passcode. The collection tool reflected numeric codes in lieu of actual patient identifiers.

\section{Protection of Human Rights}

The project proposal was presented to the University of St. Augustine's EPRC committee for approval prior to institutional review board (IRB) submission via this hospital's affiliated university. Final review by the facility's research and development committee has also verified that no human subject data is involved in the project prior to granting their final approval. Letters of support and approval are included (see Appendix L). Consent was not required for this project because delirium assessment is standard practice in the CCU. No patient harm occurred.

\section{Impact}

This evidence-based practice project could not be determined to be successful in terms of reliable reduction of ICU delirium, nor did it show any correlating reduction in LOS. The project has addressed the problem of ICU delirium by applying an evidence-based intervention, and while the data pool was reduced by the Covid pandemic, the protection of sleep has become a standard 
of care in the ICU as well as the acute care areas of this facility. Implementation occurred according to plan; it was measurement that was hindered by the pandemic, in that there were very few patients who met inclusion criteria. This huge reduction in qualifying patients secondary to Covid-19 posed the biggest limitation to the success of this project. ICU nurses reported satisfaction with the autonomy of applying the protocol, and they conveyed a sense of empowerment in using it. Several nurses reported ideas for other potential projects involving nurse-initiated protocols.

Future implications of this project include the alteration of practice across the facility by the addition of sleep enhancement measures for all patients, not just the critically ill. To further improve the practice problem, sleep enhancement will be included in annual unit education, as well as the onboarding and orientation processes. To sustain this project, chart audits will continue to be done by unit peer leaders. Plans are in place to include "sleep enhancement as a nursing intervention to reduce delirium" in an upcoming journal club discussion for continuing nursing education credit. The ICU nursing staff has been supportive of this project, and fully compliant in implementing the protocol on qualifying patients. The process measure reflecting $90 \%$ or better compliance with inservice training was met. Because super-trainers educated their peers, and advocated for sleep enhancement, they reported a deeper interest in the project outcome. One nurse said, “This wasn't another mandate; it wasn't done to us, it was done with us." Another said, "This feels like the most normal thing we have done since the pandemic began." All seem hopeful that a post-pandemic reimplementation will be successful.

\section{Dissemination}

Project culmination included a comprehensive review and evaluation of strengths, weaknesses, and opportunities for refining future use of nurse-initiated protocols in the ICU. 
Internal dissemination of the project results within the institution happened at several levels. Initially, results were presented in the unit, to nurses at their shift huddles, and then at their monthly staff meeting. First string attendees included bedside nursing staff, resident physician staff, and the nurse managers. Results were presented to facility leadership remotely using Microsoft Teams. The ICU leadership team included (in ascending order) the assistant nurse manager and manager, the chief nurse of medicine, the medical director, and the facility director. An all-staff email invitation was sent facility-wide so that every interested employee was able to attend the presentation on Teams. Results were also published in the facility newsletter.

The project manager disseminated results at their local AACN chapter monthly meeting. Even though the project did not demonstrate statistical significance the value of Clinical Significance is realized for planning future projects and the staff recognized its essentialness for patient care to reduce the potential for delirium. Journal submission provides an opportunity to disseminate information validating the benefits of NIPs and to corroborate that evidence-based practices can improve patient outcomes (Wolf, 2015). A full text will be submitted to the SOAR@USA institutional repository as a part of the DNP program completion requirements, which will also enhance the discoverability of this EBP project. Final submission to the Sigma Repository will be completed in an effort to distribute the project material worldwide.

\section{Conclusion}

The intention of this paper has been to introduce the rationale behind and the plan for an evidence-based practice change project to reduce delirium by protecting sleep and rest in an ICU. As indicated in the literature, utilizing a well-organized, evidence-based sleep enhancement protocol should reduce fragmentation of sleep and decrease the incidence of delirium with all its 
negative sequalae for this patient population. The protocol is simple and includes favorable environmental manipulation, frequent reorientation, and clustered care. There were no earplugs, eye masks, aromatherapy, or medications used in this project, though there are several published articles that advocate for them. This project sought to facilitate a protocol for the consistent use of sleep enhancement interventions in hopes of promoting uninterrupted sleep in ICU patients as evidenced by improved CAM-ICU scores and a decreased incidence of delirium. Unfortunately, the global COVID-19 pandemic erupted which severely restricted the pool of eligible patients and interrupted the expected outcome. Thankfully, the facility plans to implement the Sleep Enhancement Protocol on every floor going forward. They will reassess the effectiveness after the pandemic ends. 


\section{References}

Altman, M. T., Knauert, M. P., Murphy, T. E., Ahasic, A. M., Chauhan, Z., \& Pisani, M. A. (2018). Association of intensive care unit delirium with sleep disturbance and functional disability after critical illness: An observational cohort study. Annals of Intensive Care, 8 (63). https://doi.org/10.1186/s13613-018-0408-4

American Psychiatric Association. (2013). Diagnostic and statistical manual of mental disorders. https://doi.org/10.1176/appi.books.9780890425596

Avendano-Cespedes, A., Garcia-Cantos, N., Gonzalez-Teruel, M., Martinez-Garcia, M., Villarreal-Bocanegra, E., Oliver-Carbonell, J., \& Abizanda, P. (2016). Pilot study of a preventive multicomponent nurse intervention to reduce the incidence and severity of delirium in hospitalized older adults: MID-Nurse-P. Maturitas, 86, 86-94. https://doi.org/10.1016/j.maturitas.2016.02.002

Barr, J., Fraser, G. L., Puntillo, K., Ely, E. W., Gelinas, C., Dasta, J. F., Davidson, J. E., Devlin, J. W., Kress, J. P., Joffe, A. M., Coursin, D. B., Herr, D. L., Tung, A., Robinson, B. R., Fontaine, D. K., Ramsay, M. A., Riker, R. R., Sessler, C. N., Punn, B.,...Jaeschke, R. (2013). Clinical practice guidelines for the management of pain, agitation, and delirium in adult patients in the intensive care unit. Critical Care Medicine, 41(1). https://doi.org/10.1097/CCM.0b013e3182783b72

Birge, A. O., \& Aydin, H. T. (2017). The effect of nonpharmacological training on delirium identification and intervention strategies of intensive care nurses. Intensive and Critical Care Nursing, 41, 33-42. https://doi.org/0.1016/j.iccn.2016.08.009

Boehm, L., Pun, B. T., \& Stollings, J. (2016). Confusion Assessment Method for the ICU (CAMICU) the complete training manual (2016 Revision) [VA Training Manual]. Tennessee Valley VHA. 
Boesen, H. C., Andersen, J. H., Bendtsen, A. O., \& Jennum, P. J. (2015). Sleep and delirium in unsedated patients in the intensive care unit. Acta Anaesthesiologica Scandinavica, 60, 59-68. https://doi.org/10.1111/aas.12582

CNVAMC Volunteer Handbook [orientation pamphlet]. (n.d.). Augusta VA. https://www.augusta.va.gov/Documents/CNVAMC_Volunteer_Handbook.pdf Cunningham, B. P., Bosch, L., Swanson, D., McLemore, R., Rhorer, A. S., Parikh, H. R., Albersheim, M., \& Ortega, G. (2020). The floating flail chest: Acute management of an injury combination of the floating shoulder and flail chest. Journal of Orthopaedics, Trauma and Rehabilitation, 27(1), 10-15. https://doi.org/10.1177/2210491719899076

Dang, D., \& Dearholt, S. L. (2017). Johns Hopkins nursing evidence-based practice: Model and guidelines (3rd ed.). Sigma Theta Tau International.

Devlin, J. W., Skrobik, Y., G?linas, C., Needham, D. M., Slooter, A. C., Pandharipande, P. P., Watson, P. L., Weinhouse, G. L., Nunnally, M. E., Rochwerg, B., Balas, M. C., van den Boogaard, M., Bosma, K. J., Brummel, N. E., Chanques, G., Denehy, L., Drouot, X., Fraser, G. L., Harris, J. E.,...Alhazzani, W. (2018). Clinical practice guidelines for the prevention and management of pain, agitation/sedation, delirium, immobility, and sleep disruption in adult patients in the ICU. Critical Care Medicine, 46(9), e825-e873.

\section{https://doi.org/10.1097/ccm.0000000000003299}

Ebell, M. H., Siwek, J., Weiss, B. D., Woolf, S. H., Susman, J., Ewigman, B., \& Bowman, M. (2004). Strength of recommendation taxonomy (sort): A patient-centered approach to grading evidence in the medical literature. The Journal of the American Board of Family Medicine, 17(1), 59-67. https://doi.org/10.3122/jabfm.17.1.59

Ely, E. W. (2002). Confusion Assessment Method for the ICU (CAM-ICU) the complete training manual. http://tetaf.org/wp-content/uploads/2016/03/CAM_ICU_training.pdf 
Faraklas, I., Holt, B., Tran, S., Lin, H., Saffle, J., \& Cochran, A. (2013). Impact of a nursingdriven sleep hygiene protocol on sleep quality. Journal of Burn Care \& Research, 34(2), 249-254. https://doi.org/10.1097/bcr.0b013e318283d175

Ferguson, A., Uldall, K., Dunn, J., Blackmore, C. C., \& Williams, B. (2018). Effectiveness of a multifaceted delirium screening, prevention, and treatment initiative on the rate of delirium falls in the acute care setting. Journal of Nursing Quality, 33(3), 213-220. https://doi.org/10.1097/NCQ.0000000000000297

Hussain, S., Lei, S., Akram, T., Haider, M., Hussain, S., \& Ali, M. (2018). Kurt Lewin's change model: A critical review of the role of leadership and employee involvement in organizational change. Journal of Innovation \& Knowledge, 3(3), 123-127. https://doi.org/10.1016/j.jik.2016.07.002

Institute of Health Improvement (n.d.). Improvement Capability Self-Assessment Tool [Apparatus].

\section{http://www.ihi.org/resources/Pages/Tools/IHIImprovementCapabilitySelfAssessmentToo}

\section{1.aspx}

Inouye, S. K., Westendorp, R., \& Saczynski, J. S. (2014). Delirium in elderly people. The Lancet, 383(9920), 911-922. https://doi.org/10.1016/s0140-6736(13)60688-1

Irwin, M. R., Olmstead, R., \& Carroll, J. E. (2016). Sleep disturbance, sleep duration, and inflammation: A systematic review and meta-analysis of cohort studies and experimental sleep deprivation. Biological Psychiatry, 80(1), 40-52. https://doi.org/10.1016/j.biopsych.2015.05.014

Kamdar, B. B., Martin, J. L., Needham, D. M., \& Ong, M. K. (2016). Promoting sleep to improve delirium in the ICU. Critical Care Medicine Journal, 44(12), 2290-2291. https://doi.org/10.1097/CCM.0000000000001982 
Kram, S. L., DiBartolo, M. C., Hinderer, K., \& Jones, R. (2015). Implementation of the ABCDE bundle to improve patient outcomes in the intensive care unit in a rural community hospital. Dimensions of Critical Care Nursing, 34(5), 250-258. https://doi.org/10.1097/dcc.0000000000000129

Lewin, K. (1947). Frontiers in group dynamics. Human Relations, 1(1), 5-41. https://doi.org/10.1177/001872674700100103

Li, S.-Y., Wang, T.-J., Vivienne Wu, S. F., Liang, S.-Y., \& Tung, H.-H. (2011). Efficacy of controlling night-time noise and activities to improve patients? Sleep quality in a surgical intensive care unit. Journal of Clinical Nursing, 20(3-4), 396-407. https://doi.org/10.1111/j.1365-2702.2010.03507.x

Lincoln, A. (1865). Second Inaugural Address. Abraham Lincoln Papers at the Library of Congress, Manuscript Division (Washington, D.C.: American Memory Project, [200002]). https://doi.org/http://memory.loc.gov/ammem/alhtml/malhome.html

Martinez, F., Donoso, A., Marquez, C., \& Labarca, E. (2017). Implementing a multicomponent intervention to prevent delirium among critically ill patients. Critical Care Nurse, 37(6), 36-46. https://doi.org/10.4037/ccn2017531

McHugh, M. L. (2013). The chi-square test of independence. Biochemia Medica, 143-149. https://doi.org/10.11613/bm.2013.018

McLaughlin, D. C., Hartjes, T. M., \& Freeman, W. D. (2018). Sleep deprivation in neurointensive care unit patients from serial neurological checks: How much is too much? Journal of Neuroscience Nursing, 50(4). https://doi.org/10.1097/JNN.0000000000000378

Meyer, R. (1995). The way I see it: Focusing library vision on educational outcomes. College \& Research Libraries News, 56(5), 335-337. https://doi.org/10.5860/crln.56.5.335 
Moher, D. (2009). Preferred reporting items for systematic reviews and meta-analyses: The PRISMA statement. Annals of Internal Medicine, 151(4), 264. https://doi.org/10.7326/0003-4819-151-4-200908180-00135

Nelson, R., \& Staggers, N. (2017). Health informatics, an interprofessional approach (2nd ed.). Elsevier.

Patel, J., Baldwin, J., Bunting, P., \& Laha, S. (2014). The effect of a multicomponent multidisciplinary bundle of interventions on sleep and delirium in medical and surgical intensive care patients. Anaesthesia, 69(6), 540-549. https://doi.org/10.1111/anae.12638

Pessoa, L. S., Menezes, T. M., Gomez, N. P., Pereira, G. S., Batista, V. M., \& Vaz de Alencar, L. M. (2019). Nursing care for elderly patients with delirium in intensive care units. Journal of Nursing UFPE, 13. https://doi.org/10.5205/1981-8963.2019. 239682

Rivosecchi, R. M., Kane-Gill, S. L., Svec, S., Campbell, S., \& Smithburger, P. L. (2016). The implementation of a nonpharmacologic protocol to prevent intensive care delirium. Journal of Critical Care, 31(1), 206-211. https://doi.org/10.1016/j.jcrc.2015.09.031

Schaffer, M. A., Sandau, K. E., \& Diedrick, L. (2012). Evidence-based practice models for organizational change: Overview and practical applications. Journal of Advanced Nursing, 69(5), 1197-1209. https://doi.org/10.1111/j.1365-2648.2012.06122.x

Smith, C., \& Grami, P. (2017). Feasibility and effectiveness of a delirium prevention bundle in critically ill patients. American Journal of Critical Care, 26(1), 19-27. https://doi.org/10.4037/ajcc2017374

Smithburger, P. L., Korenoski, A. S., Kane-Gill, S. L., \& Alexander, S. A. (2017). Perceptions of family members, nurses, and physicians on involving patients' families in delirium prevention. Critical Care Nurse, 37(6), 48-57. https://doi.org/10.4037/ccn2017901 
Society of Critical Care Medicine (n.d.). Critical care statistics. Retrieved July 1, 2020, from https://www.sccm.org/Communications/Critical-Care-Statistics

Stouten, J., Rousseau, D. M., \& DeCremer, D. (2018). Successful organizational change: Integrating the management practice and scholarly literatures. Academy of Management Annals, 12(2), 752?788. https://doi.org/10.5465/annals.2016.0095

Strategic analytics for improvement and learning (SAIL). (n.d.). https://www.va.gov/qualityofcare/measure$\underline{\text { up/strategic_analytics_for_improvement_and_learning_sail.asp }}$

Sylvia, M. L., \& Terhaar, M. F. (2018). Clinical analytics and data management for the DNP (2nd ed.). Springer Publishing Company.

Vasilevskis, E. E., Chandrasekha, R., Holtze, C. H., Graves, J., Speroff,, T., Girard, T. D., Patel, M. B., Hughes, C. G., Cao, A., Pandharipande, P. P., \& Ely, E. W. (2018). The cost of ICU delirium and coma in the intensive care unit patient. Medical Care, 56(10), 890-897. https://doi.org/10.1097/MLR.0000000000000975

Wolf, L. (2015). Getting the word out: Dissemination of research results. Journal of Emergency Nursing, 41(5), 451-452. http://dx.doi.org/10.1016/j.jen.2015.06.001

Wright, D. (2005). The ultimate guide to competency assessment in health care, (3rd ed.). Creative Health Care Management. 


\section{Figure 1}

\section{PRISMA Summary}
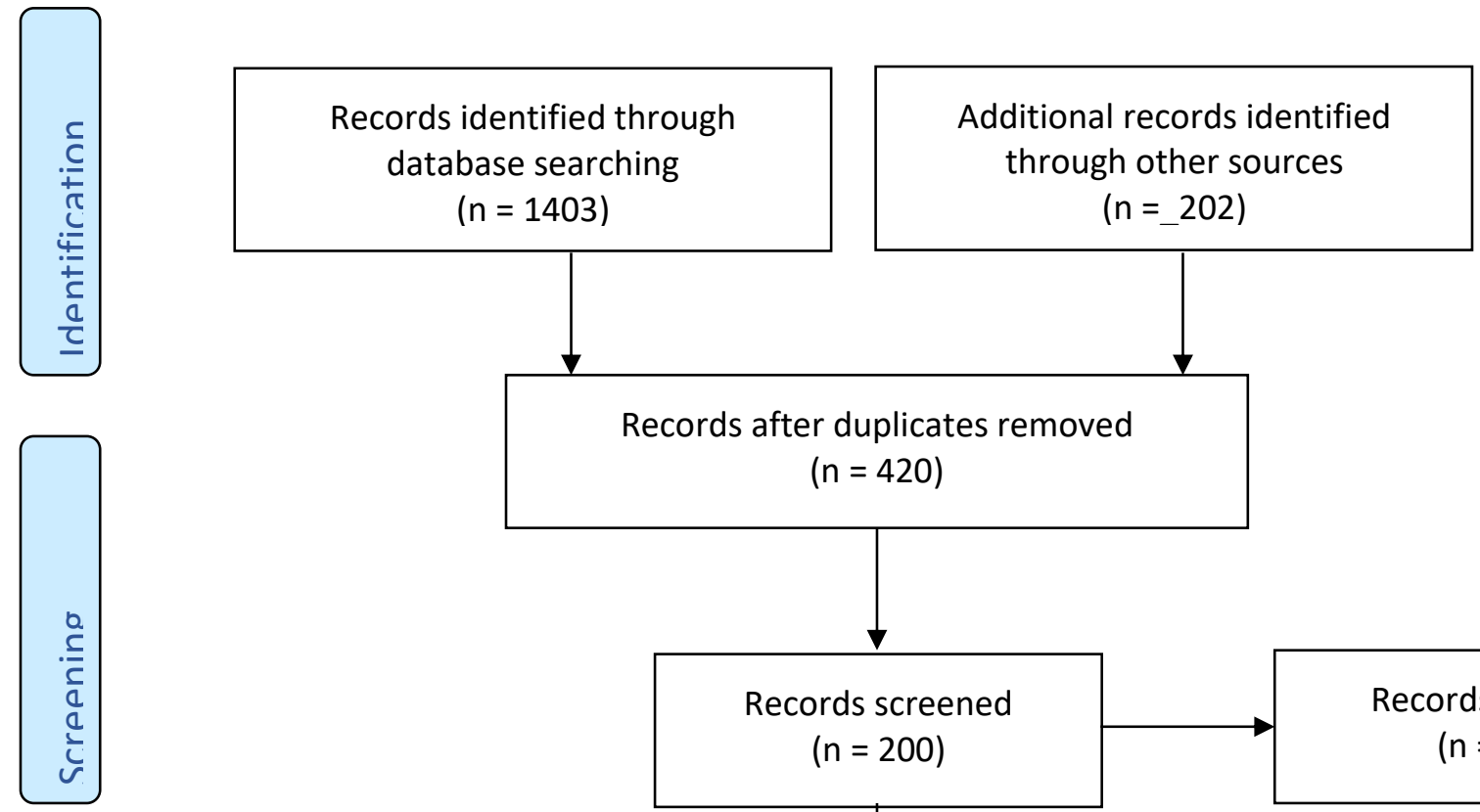

Records after duplicates removed

$$
(n=420)
$$
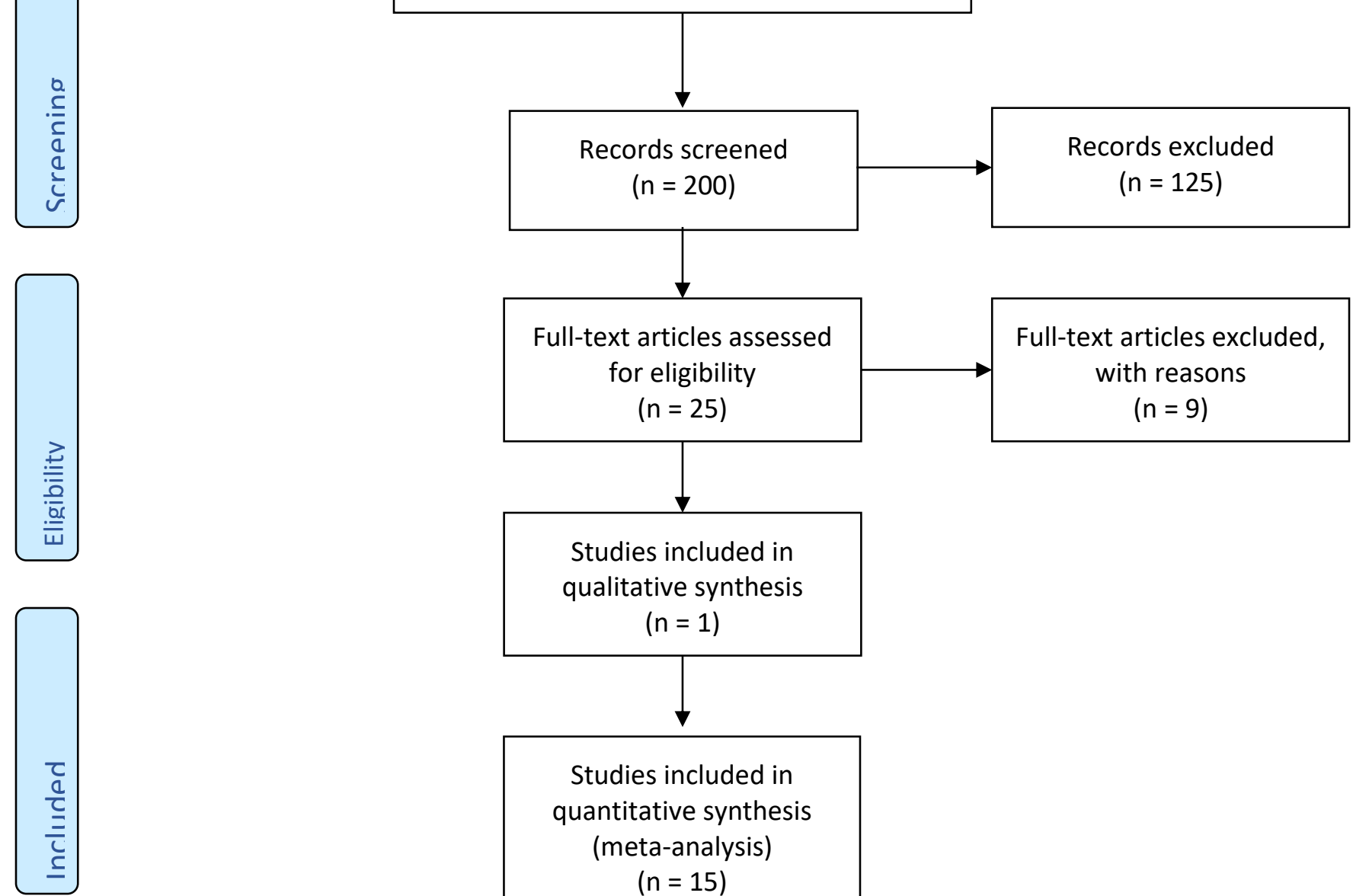

Studies included in qualitative synthesis $(n=1)$

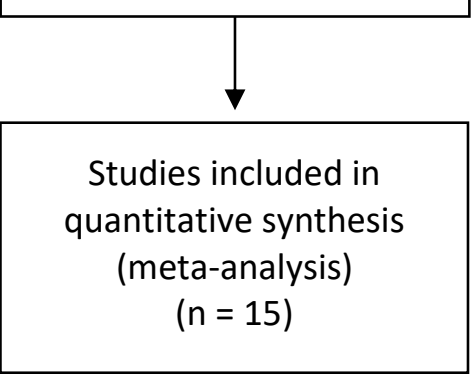

Note. Prisma flow chart diagram from "Preferred Reporting Items for Systematic Reviews and Meta-analyses: The PRISMA Statement," by D. Moher, A. Liberati, J. Tetzlaff, \& D. G. Altman, 2009, Annals of Internal Medicine, 151(4), p. 267 (http://dx.doi.org/10.7326/0003-4819-151-4-200908180-00135). Copyright 2009 by The American College of Physicians 


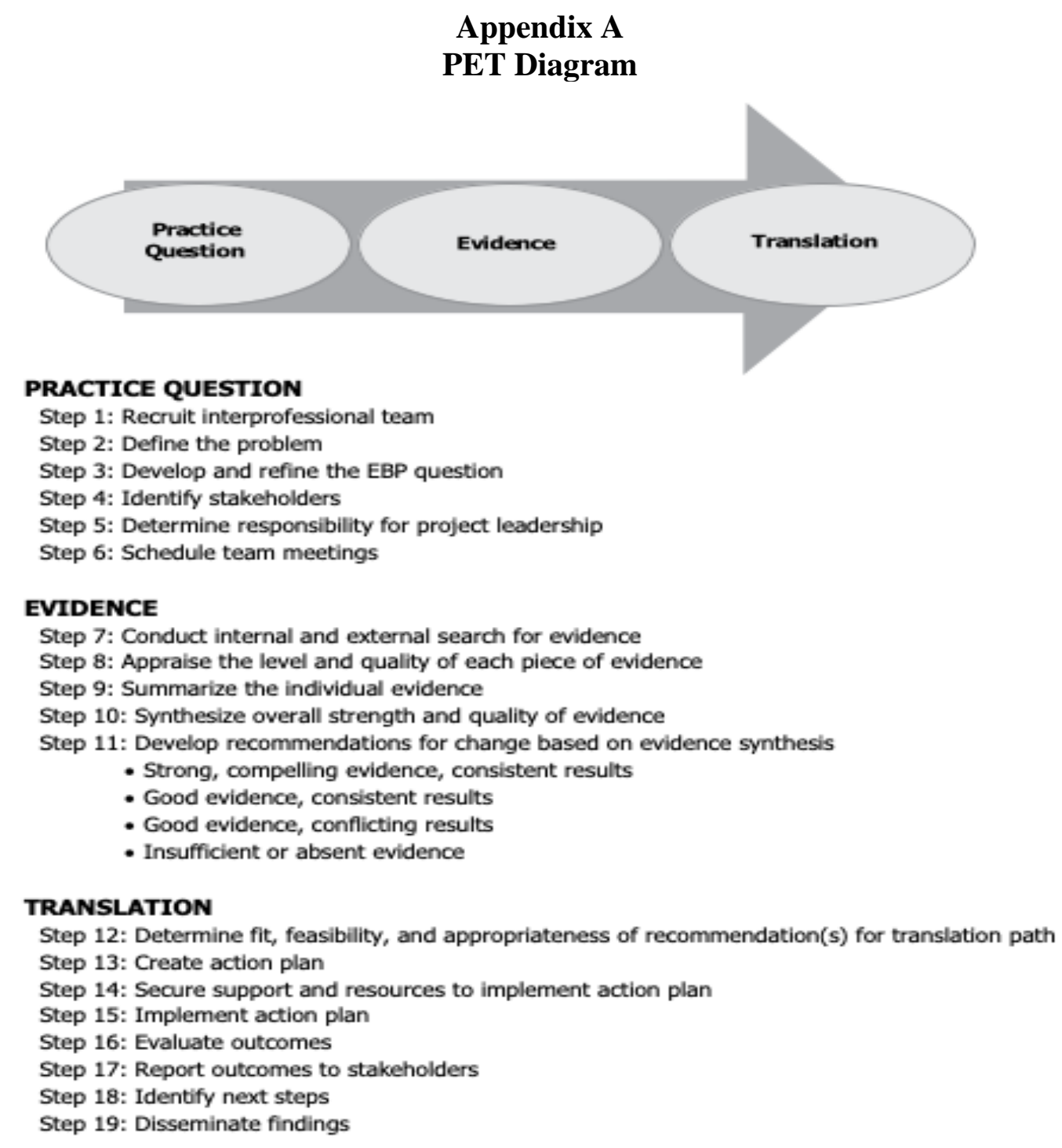

(9) 2017 The Johns Hopkins Hospital Johns Hopkins University School of Nursing

Note. PET flow chart diagram by D. Dang \& S.L. Dearholt, 2017, Johns Hopkins Nursing Evidence-Based Practice: Model and Guidelines (3rd ed.) (https://www.hopkinsmedicine.org/evidence-basedpractice/ijhn_2017_ebp.html). Copyright 2017 by The Johns Hopkins Hospital/ The Johns Hopkins University. 
Appendix B

PET Permission Letter

\begin{tabular}{|c|c|c|c|c|c|}
\hline \multirow{2}{*}{\multicolumn{4}{|c|}{ \$ JOHNS HOPKINS }} & \multirow{2}{*}{\multicolumn{2}{|c|}{ Find a course... }} \\
\hline & & & & & \\
\hline LEARNING SYSTEM HOME & COURSE CATALOG & CONTACT US & JOIN OUR MAILING LIST & IJHN WEBSITE & \\
\hline
\end{tabular}

Home » JHNEBP Model and Tools- Permission

\section{JHNEBP MODEL AND TOOLS- PERMISSION}

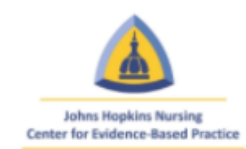

Thank you for your submission. We are happy to give you permission to use the JHNEBP model and tools in adherence of our legal terms noted below:

- You may not modify the model or the tools without written approval from Johns Hopkins.

- All reference to source forms should include "@The Johns Hopkins Hospital/The Johns Hopkins University."

- The tools may not be used for commercial purposes without special permission.

If interested in commercial use or discussing changes to the tool, please email ijhn@jhmi.edu.

Downloads:

JHNEBP Tools-Printable Version

JHNEBP Tools-Electronic Version

Note: copyright The John Hopkins Hospital/The Johns Hopkins University 
Appendix C

Summary of Primary Research Evidence

\begin{tabular}{|c|c|c|c|c|c|c|}
\hline Citation & $\begin{array}{l}\text { Design, } \\
\text { Level } \\
\text { Quality } \\
\text { Grade }\end{array}$ & $\begin{array}{l}\text { Sample type } \\
\text { Sample size }\end{array}$ & $\begin{array}{l}\text { Intervention } \\
\text { Comparison } \\
\text { (Including tools } \\
\text { used along with } \\
\text { reliability \& } \\
\text { validity) }\end{array}$ & Data Analysis & Limitations & $\begin{array}{c}\text { Usefulness } \\
\text { Results } \\
\text { Key Findings }\end{array}$ \\
\hline $\begin{array}{l}\text { Faraklas et al., } \\
2013\end{array}$ & $3 \mathrm{~B}$ & $\begin{array}{l}\text { A total of ( } \mathrm{n}=130) \\
\text { patients were } \\
\text { surveyed, pre- (n= } \\
81) \text { and post- } \\
\text { implementation } \\
\text { (n=49) in a burn- } \\
\text { trauma ICU, but } \\
\text { not all patients } \\
\text { were burned. } \\
\text { Quasi- } \\
\text { experimental study } \\
\text { using a pretest- } \\
\text { posttest design } \\
\text { (non- randomized). }\end{array}$ & $\begin{array}{l}\text { Validated } \\
\text { Richards- } \\
\text { Campbell Sleep } \\
\text { Questionnaire was } \\
\text { the survey tool } \\
\text { used for patients to } \\
\text { describe their } \\
\text { quality of sleep }\end{array}$ & & $\begin{array}{l}\text { Patients would } \\
\text { have to be alert } \\
\text { and somewhat } \\
\text { oriented (without } \\
\text { signs of delirium) } \\
\text { to use the } \\
\text { questionnaire. } \\
\text { May be useful in } \\
\text { non-delirious } \\
\text { patients participate } \\
\text { in the project. }\end{array}$ & $\begin{array}{l}\text { Post-implementation } \\
\text { patients reported falling } \\
\text { asleep faster }(\mathrm{P}=.022) \\
\text { with significant } \\
\text { improvement in falling } \\
\text { asleep ( } 9 \text { vs } 4, \mathrm{P}= \\
.002) \text { and being able to } \\
\text { go back to sleep if } \\
\text { woken up ( } 8.5 \text { vs } 5, \mathrm{P}= \\
.033) \text {. } \\
\text { Post-implementation } \\
\text { patients complained } \\
\text { less often than pre- } \\
\text { implementation patients } \\
\text { did about sleep. }\end{array}$ \\
\hline $\begin{array}{l}\text { Patel et al., } \\
2014\end{array}$ & $3 \mathrm{~B}$ & $\begin{array}{l}\text { Mixed ICU, } \\
n=338,24-\text { bed } \\
\text { ICU, academic } \\
\text { hospital in UK }\end{array}$ & $\begin{array}{l}\text { CAM-ICU, RCSQ, } \\
\text { sleep efficiency } \\
\text { index }\end{array}$ & $\begin{array}{l}\text { Mixed } \\
\text { methodology }\end{array}$ & $\begin{array}{l}\text { Nonrandomized } \\
\text { cohorts and single- } \\
\text { center design } \\
\text { (selection bias), } \\
\text { tools used relied }\end{array}$ & $\begin{array}{l}\text { Improvements in all } \\
\text { components of RCSQ } \\
(\mathrm{p}<0.05) ; \text { improved } \\
\text { sleep time }(\mathrm{p}<0.001) \\
\text { and }>3 \mathrm{hr} \text { of sleep }\end{array}$ \\
\hline
\end{tabular}




\begin{tabular}{|c|c|c|c|c|c|c|}
\hline & & Pre/post cohort & & & $\begin{array}{l}\text { upon self- } \\
\text { assessment }\end{array}$ & $\begin{array}{l}\text { window }(\mathrm{p}=0.029) \text {; } \\
\text { improved sleep } \\
\text { efficiency index } \\
(\mathrm{p}<0.001) ;\end{array}$ \\
\hline $\begin{array}{l}\text { Altman et al., } \\
2018\end{array}$ & $2 \mathrm{~B}$ & $\begin{array}{l}\text { Sample Size: This } \\
\text { observational } \\
\text { cohort sample was } \\
\text { made up of patients } \\
\text { with an expected } \\
\text { ICU length of stay } \\
>24 \text { hours. } 422 \\
\text { were enrolled, of } \\
\text { which } 327 \text { were } \\
\text { eligible for follow- } \\
\text { up for up to } 1 \text { year } \\
\text { post-discharge. } \\
\text { Observational } \\
\text { cohort study }\end{array}$ & $\begin{array}{l}\text { CAM-ICU, PSQI, } \\
\text { BADLs/ IADLs }\end{array}$ & $\begin{array}{l}\text { Data Analysis: } \\
\text { Linear regression } \\
\text { analysis was } \\
\text { used to assess } \\
\text { change in } \\
\text { disability from } \\
\text { baseline to } \\
\text { follow-up. }\end{array}$ & & $\begin{array}{l}\text { ICU, sleep disturbances } \\
\text { and functional } \\
\text { disability were greatly } \\
\text { increased. } \\
\text { The greater number of } \\
\text { days patients } \\
\text { experienced delirium in } \\
\text { the ICU, the worse } \\
\text { sleep quality was on } \\
\text { follow-up. } \\
\text { Patients who } \\
\text { experienced ICU } \\
\text { delirium had greater } \\
\text { prevalence of disability } \\
\text { on follow-up. }\end{array}$ \\
\hline $\begin{array}{l}\text { Ferguson et } \\
\text { al., } 2018\end{array}$ & 1B & $\begin{array}{l}\text { Research Design: } \\
\text { A retrospective } \\
\text { cohort study using } \\
\text { chart reviews was } \\
\text { done to assess the } \\
\text { prevalence of } \\
\text { delirium-associated } \\
\text { inpatient falls. }\end{array}$ & $\begin{array}{l}\text { Research Tools Used: } \\
\text { JHFRAT, CAM, } \\
\text { CAM-ICU, LDT }\end{array}$ & $\begin{array}{l}\text { Data Analysis: } \\
\text { Comparison of } \\
\text { pre- and post- } \\
\text { intervention was } \\
\text { done using t-test. } \\
\text { Interrupted time } \\
\text { series regression } \\
\text { was graphed. All } \\
\text { data analysis was }\end{array}$ & $\begin{array}{l}\text { Specific to falls; } \\
\text { speaks to } \\
\text { importance of } \\
\text { nurses' } \\
\text { involvement and } \\
\text { to other negative } \\
\text { outcomes } \\
\text { associated with } \\
\text { development of } \\
\text { delirium. This }\end{array}$ & $\begin{array}{l}\text { Nurses are integral to } \\
\text { the success of a } \\
\text { delirium screening/ } \\
\text { prevention/ treatment } \\
\text { program. } \\
\text { Delirium screening and } \\
\text { prevention reduces } \\
\text { patient falls. }(0.91 \text { per } \\
\text { thousand patient days, }\end{array}$ \\
\hline
\end{tabular}




\begin{tabular}{|c|c|c|c|c|c|c|}
\hline & & & & $\begin{array}{l}\text { done by STATA } \\
\text { v. } 12.0\end{array}$ & $\begin{array}{l}\text { could be an } \\
\text { anecdotal QI } \\
\text { measure. }\end{array}$ & $\begin{array}{l}\text { down to } 0.50 \text { in this } \\
\text { study) }\end{array}$ \\
\hline $\begin{array}{l}\text { Smithburger et } \\
\text { al., } 2017\end{array}$ & $3 B$ & $\begin{array}{l}\text { Research Design: } \\
\text { Two surveys (one } \\
\text { for MDs and RNs, } \\
\text { the other for the } \\
\text { patients' } \\
\text { surrogates) were } \\
\text { designed and } \\
\text { given. For the MDs } \\
\text { and RNs the goal } \\
\text { was to determine } \\
\text { current practice } \\
\text { and opinion } \\
\text { regarding delirium } \\
\text { prevention and } \\
\text { family } \\
\text { involvement. For } \\
\text { the surrogates, the } \\
\text { goal was to } \\
\text { determine } \\
\text { willingness to be } \\
\text { involved in the } \\
\text { same. } \\
\text { Sample Size: Over } \\
\text { a } 9 \text { month period, } \\
\text { surrogates who } \\
\text { spoke English, and } \\
\text { whose loved ones } \\
\text { had been in the } \\
\text { ICU at least } 48\end{array}$ & $\begin{array}{l}\text { Research Tools } \\
\text { Used: Surveys } \\
\text { using a } \\
\text { combination of } \\
\text { Likert scale, } \\
\text { yes/no answers, } \\
\text { and fill-in-the- } \\
\text { blanks were } \\
\text { administered. }\end{array}$ & $\begin{array}{l}\text { Data Analysis: } \\
\text { Descriptive } \\
\text { statistics using } \\
\text { the Mann- } \\
\text { Whitney } U \text { test } \\
\text { compared MD } \\
\text { and RN } \\
\text { responses to the } \\
\text { survey. }\end{array}$ & $\begin{array}{l}\text { Study focuses on } \\
\text { the intervention of } \\
\text { family members, } \\
\text { now part of the } \\
\text { ABCDEF bundle, } \\
\text { for the purpose of } \\
\text { reducing delirium } \\
\text { in ICU. }\end{array}$ & $\begin{array}{l}\text { Patient surrogates are } \\
\text { willing to be involved } \\
\text { in nonpharmacologic } \\
\text { prevention of delirium. } \\
\text { One of their fears is } \\
\text { inadvertently pulling } \\
\text { out a catheter or tube. } \\
\text { Another is physically } \\
\text { being in the way of the } \\
\text { nurses. } \\
\text { Healthcare providers } \\
\text { should involve patients' } \\
\text { families in delirium } \\
\text { prevention measures. } \\
\text { CAM-ICU results } \\
\text { should be included in } \\
\text { ICU daily rounds } \\
\text { because while RNs } \\
\text { frequently assess for } \\
\text { delirium, MDs rarely } \\
\text { use the information } \\
\text { rendered. }\end{array}$ \\
\hline
\end{tabular}




\begin{tabular}{|c|c|c|c|c|c|c|}
\hline & & $\begin{array}{l}\text { hours were invited } \\
\text { to participate by } \\
\text { completing a } 20- \\
\text { question survey. } \\
\text { There were } 60 \\
\text { respondents. } \\
\text { RNs and MDs } \\
\text { were invited to } \\
\text { complete a 19- } \\
\text { question survey. }\end{array}$ & & & & \\
\hline $\begin{array}{l}\text { McLaughlin et } \\
\text { al., } 2018\end{array}$ & $2 \mathrm{~B}$ & $\begin{array}{l}\text { Research Design: } \\
\text { This was a } \\
\text { prospective } \\
\text { observational } \\
\text { cohort design } \\
\text { without a } \\
\text { convenience } \\
\text { sample, using chart } \\
\text { reviews. } \\
\text { Sample Size: All } \\
\text { patients admitted to } \\
\text { this NICU over a } \\
\text { 6-month period } \\
\text { were included if } \\
\text { their GCS was >8, } \\
\text { they stayed in the } \\
\text { NICU longer than } \\
48 \text { hours, were not } \\
\text { prisoners or } \\
\text { pregnant, were not } \\
\text { both deaf and }\end{array}$ & $\begin{array}{l}\text { Research Tools } \\
\text { Used: CAM-ICU, } \\
\text { GCS, APACHE II, }\end{array}$ & $\begin{array}{l}\text { Data Analysis: } \\
\text { Demographics } \\
\text { were put into a } \\
\text { REDCap } \\
\text { database for } \\
\text { analysis }\end{array}$ & $\begin{array}{l}\text { Based in Neuro- } \\
\text { specific ICU }\end{array}$ & $\begin{array}{l}\text { Hourly neuro checks } \\
\text { after the } 48^{\text {th }} \text { hour } \\
\text { render limited useful } \\
\text { data and may be } \\
\text { harmful due to resulting } \\
\text { sleep deprivation } \\
\text { leading to delirium, } \\
\text { which increases } \\
\text { morbidity and cost. } \\
\text { Implement de- } \\
\text { escalation protocol for } \\
\text { neuro exam frequency } \\
\text { in the NICU. }\end{array}$ \\
\hline
\end{tabular}




\begin{tabular}{|c|c|c|c|c|c|c|}
\hline & & $\begin{array}{l}\text { blind, and could } \\
\text { consent. } 99 \\
\text { patients were } \\
\text { screened and } 20\end{array}$ & & & & \\
\hline $\begin{array}{l}\text { Kram et al., } \\
2015\end{array}$ & $5 B$ & $\begin{array}{l}\text { Retrospective } \\
\text { quality } \\
\text { improvement study } \\
\text { Total charts } \\
\text { reviewed= } 159 \text { ( } 80 \\
\text { pre, } 79 \text { post }\end{array}$ & $\begin{array}{l}\text { Patients were } \\
\text { assessed for } \\
\text { delirium using the } \\
\text { ICDSC. }\end{array}$ & & $\begin{array}{l}\text { Lowest strength of } \\
\text { evidence } \\
\text { Did not use CAM- } \\
\text { ICU }\end{array}$ & $\begin{array}{l}\text { Use of the ABCDE } \\
\text { bundle led to } \\
\text { significant decreases in } \\
\text { the prevalence (from } \\
38 \% \text { to } 23 \%, \mathrm{P}=.01 \text { ) } \\
\text { and duration (from } 3.8 \\
\text { to } 1.72 \text { days, } \mathrm{P}<.001 \text { ). } \\
\text { The number of patients } \\
\text { without delirium } \\
\text { increased significantly } \\
\text { after ABCDE (from } \\
62 \% \text { to } 77 \% ; \mathrm{P}=.01 \text { ). }\end{array}$ \\
\hline $\begin{array}{l}\text { Rivosecchi et } \\
\text { al., } 2016\end{array}$ & $2 \mathrm{~B}$ & $\begin{array}{l}\text { Prospective } \\
\text { observational } \\
\text { study; pre/post } \\
\text { implementation } \\
\text { design (230/253 } \\
\text { patients } \\
\text { respectively) }\end{array}$ & $\begin{array}{l}\text { Intensive Care } \\
\text { Delirium } \\
\text { Screening } \\
\text { Checklist (ICDSC) } \\
\text { given every } 4 \\
\text { hours }\end{array}$ & $\begin{array}{l}\text { Statistical data } \\
\text { managed via } \\
\text { RedCap and } \\
\text { analyzed with } \\
\text { SPSS online. } \\
\text { Mann-Whitney } \\
\text { and x2 were used } \\
\text { to describe and } \\
\text { compare the two } \\
\text { groups. }\end{array}$ & $\begin{array}{l}\text { Described inability } \\
\text { to track nursing } \\
\text { adherence to the } \\
\text { protocol }\end{array}$ & $\begin{array}{l}\text { Protocol reduced the } \\
\text { odds of delirium } \\
\text { development by } 57 \% \\
\text { Heavily involved unit- } \\
\text { level leadership } \\
\text { facilitated project } \\
\text { success. }\end{array}$ \\
\hline $\begin{array}{l}\text { Kamdar et al., } \\
2016\end{array}$ & $5 B$ & $\begin{array}{l}\mathrm{N}=300 \text { medical } \\
\text { ICU patients, } \\
\text { sleep- promoting } \\
\text { interventions }\end{array}$ & $\begin{array}{l}\text { Daily RCSQ, } \\
\text { Patients were } \\
\text { assessed twice } \\
\text { daily for delirium } \\
\text { using the CAM- }\end{array}$ & $\begin{array}{l}\text { Systematic } \\
\text { review/ editorial }\end{array}$ & $\begin{array}{l}\text { Lowest strength of } \\
\text { evidence }\end{array}$ & $\begin{array}{l}\text { Improved daily noise } \\
\text { ratings ( } \mathrm{p}=0.001), \\
\text { incidence of delirium, } \\
(\mathrm{p}=<0.02) \text {, no } \\
\text { significant LOS } \\
\text { findings }\end{array}$ \\
\hline
\end{tabular}




\begin{tabular}{|c|c|c|c|c|c|c|}
\hline & & $\begin{array}{l}\text { Quality } \\
\text { Improvement } \\
\text { project }\end{array}$ & $\begin{array}{l}\text { ICU, and sedation } \\
\text { using RASS }\end{array}$ & & & \\
\hline $\begin{array}{l}\text { Smith \& } \\
\text { Grammi, } 2017\end{array}$ & $1 \mathrm{~A}$ & $\begin{array}{l}\text { RCT (Control } \\
\text { group: no delirium } \\
\text { protocol in an } 18 \\
\text { bed ICU. } \\
\text { Intervention group: } \\
10 \text { bed ICU) } \\
447 \text { patients total }\end{array}$ & $\begin{array}{l}\text { Outcomes } \\
\text { measures: } \\
\text { ventilator days, } \\
\text { days in restraints, } \\
\text { and LOS in ICU. } \\
\text { RCT found } \\
\text { Intervention group } \\
\text { experienced highly } \\
\text { significant (78\%) } \\
\text { reduction in } \\
\text { relative risk for } \\
\text { delirium (odds } \\
\text { ratio, } 0.22 ; 95 \% \\
\text { CI, } 0.08-0.56 ; \mathrm{P}= \\
.001) .\end{array}$ & $\begin{array}{l}\text { Analyzation via } \\
\text { linear regression } \\
\text { model }\end{array}$ & $\begin{array}{l}\text { Randomization } \\
\text { was by unit, not by } \\
\text { patient. } \\
\text { Lack of daily } \\
\text { sedation-vacation } \\
\text { protocol was a } \\
\text { study limitation as } \\
\text { well }\end{array}$ & $\begin{array}{l}\text { Delirium is associated } \\
\text { with increased LOS in } \\
\text { the ICU, longer use of } \\
\text { mechanical ventilation, } \\
\text { and use of restraints. } \\
\text { A delirium prevention } \\
\text { bundle was effective in } \\
\text { this ICU }\end{array}$ \\
\hline $\begin{array}{l}\text { Birge \& } \\
\text { Aydin, } 2017\end{array}$ & 3B & $\begin{array}{l}\text { Non-randomized } \\
\text { quasi- } \\
\text { experimental study } \\
\text { using a pretest- } \\
\text { posttest design } \\
\\
\text { There were patients } \\
(\mathrm{n}=95) \text { and nurses } \\
(\mathrm{n}=19) \text { in a } \\
\text { Medical ICU in a } \\
\text { academic/ teaching } \\
\text { hospital. }\end{array}$ & $\begin{array}{l}\text { The patients were } \\
\text { evaluated using } \\
\text { the Patient } \\
\text { Introduction Form, } \\
\text { Delirium Risk } \\
\text { Factors Form, and } \\
\text { (CAM)- ICU. } \\
\text { The nurses were } \\
\text { evaluated using } \\
\text { the Nurse } \\
\text { Introduction and } \\
\text { the }\end{array}$ & $\begin{array}{l}\text { Statistical } \\
\text { analysis using } \\
\text { SPSS v21. Non- } \\
\text { parametric Chi- } \\
\text { square test or } \\
\text { Fisher's exact } \\
\text { tests were used } \\
\text { to assess } \\
\text { quantitative } \\
\text { variables. } \\
\text { Logistic } \\
\text { regression }\end{array}$ & $\begin{array}{l}\text { Lack of } \\
\text { randomization }\end{array}$ & $\begin{array}{l}\text { Delirium was identified } \\
\text { in } 26.5 \% \text { of patients in } \\
\text { the pre-test phase and } \\
20.9 \% \text { of the patients in } \\
\text { the post-test phase. } \\
\text { Patients with delirium } \\
\text { had a longer LOS in } \\
\text { ICU (p <0.05) } \\
\text { There was an increased } \\
\text { incidence of using } \\
\text { nonpharmacological }\end{array}$ \\
\hline
\end{tabular}




\begin{tabular}{|c|c|c|c|c|c|c|}
\hline & & & $\begin{array}{l}\text { Nonpharmacolo } \\
\text { gical Interventions } \\
\text { in Delirium } \\
\text { Prevention forms. } \\
\text { Delirium } \\
\text { recognition rate, } \\
\text { ICU LOS, patient } \\
\text { GCS rating, and } \\
\text { number of } \\
\text { medications } \\
\text { patient received } \\
\text { daily were also } \\
\text { measured. }\end{array}$ & $\begin{array}{l}\text { analysis } \\
\text { determined the } \\
\text { effect of } \\
\text { significant } \\
\text { variables. }\end{array}$ & & $\begin{array}{l}\text { interventions for } \\
\text { delirium prevention in } \\
\text { the post- training phase. } \\
\text { Ultimately, no } \\
\text { significant difference in } \\
\text { rate of delirium was } \\
\text { realized, the training on } \\
\text { nonpharmacological } \\
\text { interventions for } \\
\text { delirium prevention did } \\
\text { increase the delirium } \\
\text { recognition rate of } \\
\text { nurses. }\end{array}$ \\
\hline $\begin{array}{l}\text { Avendaño - } \\
\text { Céspedes et } \\
\text { al., } 2016\end{array}$ & $1 \mathrm{~A}$ & $\begin{array}{l}\text { Parallel-group } \\
\text { double-blind } \\
\text { randomized } \\
\text { clinical trial (pilot } \\
\text { Study). }\end{array}$ & $\begin{array}{l}\text { Daily delirium } \\
\text { screening using } \\
\text { CAM - ICU, and } \\
\text { severity } \\
\text { assessment using } \\
\text { the Delirium } \\
\text { Rating Scale- } \\
\text { Revised- } 98 \\
\text { (DRS). }\end{array}$ & $\begin{array}{l}\text { Outcome } \\
\text { measures: } \\
\text { delirium } \\
\text { incidence/ } \\
\text { prevalence/ } \\
\text { severity/ and } \\
\text { length of time } \\
\text { spent delirious, } \\
\text { mortality, LOS, } \\
\text { use of physical } \\
\text { limb restraints, } \\
\text { and whether or } \\
\text { not medications } \\
\text { were used to } \\
\text { control delirium. }\end{array}$ & $\begin{array}{l}\text { Assessed using } \\
\text { CAM scores, but } \\
\text { not specifically } \\
\text { ICU. Pilot study } \\
\text { was done in an } \\
\text { Adult-geriatric } \\
\text { unit in Spain. }\end{array}$ & $\begin{array}{l}\text { Delirium prevalence } \\
(33.3 \% \text { vs } 48.3 \%) \text { and } \\
\text { incidence }(14.3 \% \text { vs } \\
41.4 \% ; \mathrm{p}=0.039) \text { were } \\
\text { decreased in the } \\
\text { intervention group } \\
\text { compared to the control } \\
\text { group. } \\
\text { Total delirium severity } \\
\text { was decreased in the } \\
\text { intervention group } \\
\text { compared to the control } \\
\text { group (35.0 vs } 65.0 ; \mathrm{p}= \\
0.040) .\end{array}$ \\
\hline
\end{tabular}




\begin{tabular}{|c|c|c|c|c|c|c|}
\hline $\begin{array}{l}\text { Martinez et } \\
\text { al., } 2017\end{array}$ & $3 \mathrm{~B}$ & $\begin{array}{l}\text { Non-randomized } \\
\text { quasi- } \\
\text { experimental study } \\
\text { using a pretest- } \\
\text { posttest design. } \\
\mathrm{N}=287 \text { patients ( } 60 \\
\text { pre, } 227 \text { post) }\end{array}$ & $\begin{array}{l}\text { Delirium incidence } \\
\text { was measured } \\
\text { twice per day with } \\
\text { CAM-ICU. }\end{array}$ & $\begin{array}{l}\text { Descriptive } \\
\text { statistics, Fisher } \\
\text { exact test. } \\
\text { Comparisons by } \\
\text { Mann-Whitney } \\
\text { with multivariate } \\
\text { logistic regression } \\
\text { to correct for } \\
\text { potential } \\
\text { confounders. }\end{array}$ & $\begin{array}{l}\text { Lack of } \\
\text { randomization and } \\
\text { possibility of } \\
\text { imbalances between } \\
\text { study groups }\end{array}$ & $\begin{array}{l}\text { During the } \\
\text { interventional period, } \\
\text { delirium developed in } \\
55 \text { of } 287 \mathrm{~s} \text { patients } \\
(24 \% \text {; } 95 \% \text { CI, } 19.0 \% \text { - } \\
30.7 \%) \text {, a significant } \\
\text { reduction when } \\
\text { compared with the } \\
\text { diagnostic phase (RR, } \\
0.64 ; 95 \% \text { CI, } 0.43- \\
0.95 ; \\
P=.03) \text {. } \\
\text { The intervention } \\
\text { significantly reduced } \\
\text { delirium (from } 38 \% \text { to } \\
24 \% \text {; relative risk, } 0.62 \text {; } \\
95 \% \text { CI, } 0.40-0.94 ; \mathrm{P}= \\
.02) \\
\text { Nurse-led interventions } \\
\text { had the highest } \\
\text { adherence rates } \\
\text { (>85\%), and } \\
\text { interventions led by } \\
\text { family members had } \\
\text { the lowest compliance. }\end{array}$ \\
\hline $\begin{array}{l}\text { Boesen et al., } \\
2015\end{array}$ & $2 \mathrm{~B}$ & $\begin{array}{l}\text { Research Design: } \\
\text { Prospective } \\
\text { observational study } \\
\text { Sample Size: } 14 \\
\text { patients from a } \\
\text { mixed ICU }\end{array}$ & $\begin{array}{l}\text { Research Tools } \\
\text { Used: PSG, CAM- } \\
\text { ICU, SAS }\end{array}$ & $\begin{array}{l}\text { Data Analysis: } \\
\text { The presence of } \\
\text { sleep was scored } \\
\text { using semi- } \\
\text { quantitative } \\
\text { analysis, which } \\
\text { the authors }\end{array}$ & $\begin{array}{l}\text { Small sample size } \\
\text { PSG is expensive } \\
\text { and cannot be used } \\
\text { in this project. } \\
\text { This article was to } \\
\text { reference quality }\end{array}$ & $\begin{array}{l}\text { There is a link between } \\
\text { sleep quality and } \\
\text { occurrence of delirium } \\
\text { in non-sedated, } \\
\text { ventilated patients in } \\
\text { the ICU. }\end{array}$ \\
\hline
\end{tabular}




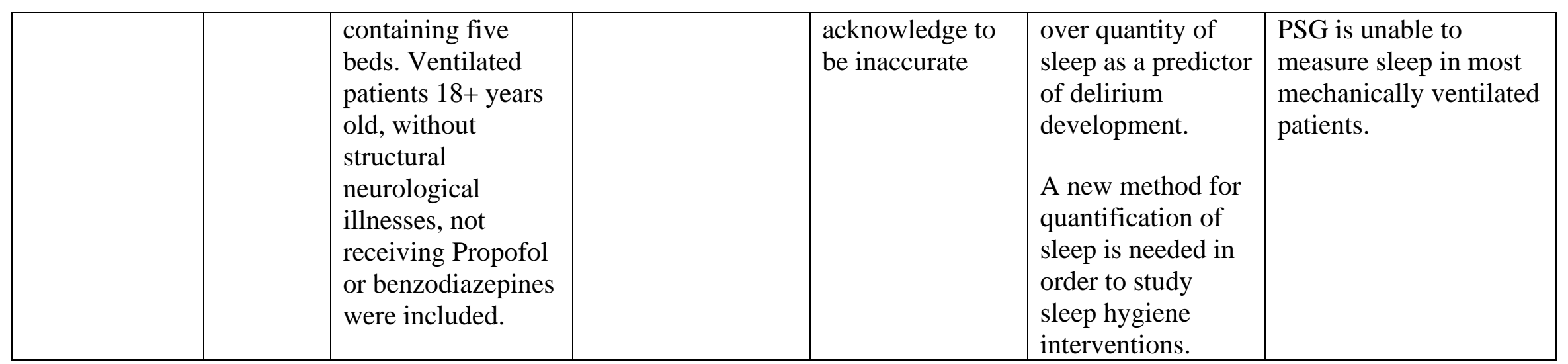


Legend:

ABCDE/ ABCDEF bundle: Awakening Breathing Circulation Delirium Early mobility Family APACHE II: Acute Physiology and Chronic Health Disease Classification System II BADLs: Basic Activities of Daily Living

CAM: Confusion Assessment Method

CAM-ICU: Confusion Assessment Method in the Intensive Care Unit

GCS: Glascow Coma Scale

IADLs: Instrumental Activities of Daily Living

ICDSC: Intensive Care Delirium Screening Checklist

JHFRAT: Johns Hopkins Fall Risk Assessment Tool

LDT: the Language of Delirium Tool

MD: Medical Doctor

NICU: Neurological Intensive Care Unit

NIHSS: National Institutes of Health Stroke Scale

PSG: Polysomnography

PSQI: Pittsburg Sleep Quality Index

QI: Quality Improvement

RCSQ: Richards- Campbell Sleep Questionnaire

RN: Registered Nurse

SAS: Sedation Agitation Scale

SORT: Strength of Recommendation Taxonomy (Ebell, et al., 2004) 


\section{Appendix D}

Summary of Systematic Reviews

\begin{tabular}{|c|c|c|c|c|c|}
\hline Citation & $\begin{array}{l}\text { Design, } \\
\text { Method }\end{array}$ & $\begin{array}{l}\text { Sample size, } \\
\text { setting }\end{array}$ & $\begin{array}{l}\text { Data } \\
\text { Analysis }\end{array}$ & Key Findings & $\begin{array}{l}\text { Quality \& level } \\
\text { of evidence }\end{array}$ \\
\hline Barret al., 2013 & $\begin{array}{l}\text { Practice- } \\
\text { guidelines, } \\
\text { based on } \\
\text { systematic } \\
\text { review of } \\
\text { RCTs. }\end{array}$ & & $\begin{array}{l}\text { The } \\
\text { Confusion } \\
\text { Assessment } \\
\text { Method for } \\
\text { the ICU } \\
\text { (CAM- } \\
\text { ICU) and } \\
\text { the } \\
\text { Intensive } \\
\text { Care } \\
\text { Delirium } \\
\text { Screening } \\
\text { Checklist } \\
\text { (ICDSC) } \\
\text { are the most } \\
\text { valid and } \\
\text { reliable } \\
\text { delirium } \\
\text { monitoring } \\
\text { tools in } \\
\text { adult ICU } \\
\text { patients (A). }\end{array}$ & $\begin{array}{l}\text { These guidelines provide a } \\
\text { guide for developing } \\
\text { evidence-based, best } \\
\text { practice protocols for } \\
\text { integrating the } \\
\text { management of pain, } \\
\text { agitation, and delirium } \\
\text { (PAD) in critically ill } \\
\text { patients. Also recommend } \\
\text { routine (feasible) } \\
\text { monitoring of delirium in } \\
\text { adult ICU patients and } \\
\text { optimizing their } \\
\text { environments, using } \\
\text { strategies to control light } \\
\text { and noise, clustering } \\
\text { patient care activities, and } \\
\text { decreasing stimuli at night } \\
\text { to protect patients' sleep } \\
\text { cycles. } \\
\text { Outcomes associated with } \\
\text { delirium: increased } \\
\text { mortality, prolonged ICU } \\
\text { and hospital LOS in adult } \\
\text { ICU patients (A). } \\
\text { It is associated with the } \\
\text { development of post-ICU } \\
\text { cognitive impairment in } \\
\text { adult ICU patients (B). }\end{array}$ & SORT 1A \\
\hline
\end{tabular}




\begin{tabular}{|c|c|c|c|c|c|}
\hline Pessoa et al., 2019 & $\begin{array}{l}\text { Integrative } \\
\text { literature } \\
\text { review which } \\
\text { asked," What is } \\
\text { the evidence } \\
\text { from the } \\
\text { literature about } \\
\text { nursing care } \\
\text { measures for } \\
\text { prevention, } \\
\text { detection and } \\
\text { management of } \\
\text { delirium in } \\
\text { elderly patients } \\
\text { admitted to } \\
\text { Intensive Care } \\
\text { Units?" }\end{array}$ & $\begin{array}{l}\text { Six articles: } \\
\text { three qualitative, } \\
\text { three } \\
\text { quantitative } \\
\text { were included in } \\
\text { the review } \\
\text { Most studies } \\
\text { were excluded } \\
\text { due to their } \\
\text { focus on the } \\
\text { general adult } \\
\text { population rather } \\
\text { than the elderly } \\
\text { population. }\end{array}$ & $\begin{array}{l}\text { Data } \\
\text { collection } \\
\text { from 12/1 } \\
\text { thru 12/31, } \\
2018 . \\
\text { CAM-ICU } \\
\text { ICDSC } \\
\text { were the } \\
\text { delirium } \\
\text { assessment } \\
\text { tools } \\
\text { represented } \\
\text { in the } \\
\text { articles } \\
\text { reviewed. }\end{array}$ & $\begin{array}{l}\text { Of } 271 \text { articles in four } \\
\text { databases only } 6 \text { were } \\
\text { selected. Content Analysis } \\
\text { technique was applied and } \\
\text { the following categories } \\
\text { emerged: } \\
\text { 1) Prevention, } \\
\text { identification and } \\
\text { management of delirium by } \\
\text { the nursing team in elderly } \\
\text { patients admitted to ICUs; } \\
\text { and } \\
\text { 2) } \\
\text { Nursing teams in ICU } \\
\text { Nurses do not routinely } \\
\text { use CAM-ICU in their } \\
\text { assessments. } \\
\text { Nurses are more likely to } \\
\text { recognize hyperactive } \\
\text { delirium. }\end{array}$ & SORT 1A \\
\hline Trogrlic et al., 2015 & $\begin{array}{l}\text { Systematic } \\
\text { review of } 21 \\
\text { studies which } \\
\text { looked at } \\
\text { implementation } \\
\text { strategies for } \\
\text { assessment, } \\
\text { prevention, and } \\
\text { management of } \\
\text { ICU delirium } \\
\text { and their }\end{array}$ & $\begin{array}{l}\text { Of the } 21 \\
\text { studies, } 17 \text { were } \\
\text { RCTs and four } \\
\text { were } \\
\text { prospective/ } \\
\text { retrospective } \\
\text { studies. All were } \\
\text { set in ICUs. }\end{array}$ & $\begin{array}{l}\text { Outcomes } \\
\text { such as } \\
\text { mortality } \\
\text { and LOS } \\
\text { were } \\
\text { measured. } \\
\text { Mortality } \\
\text { and ICU } \\
\text { LOS } \\
\text { decreases } \\
\text { were }\end{array}$ & $\begin{array}{l}\text { Multi- component } \\
\text { implementation programs } \\
\text { (ie bundles) have better } \\
\text { outcomes than single } \\
\text { implementation } \\
\text { interventions regarding } \\
\text { ICU delirium. }\end{array}$ & SORT 1A \\
\hline
\end{tabular}




\begin{tabular}{|l|l|l|l|l|}
\hline & $\begin{array}{l}\text { effects on } \\
\text { clinical } \\
\text { outcomes }\end{array}$ & & $\begin{array}{l}\text { realized in } \\
10 \text { studies. } \\
\text { One study } \\
\text { found } \\
\text { decrease in } \\
\text { LOS, but } \\
\text { not } \\
\text { mortality. }\end{array}$ \\
& & & \\
\hline
\end{tabular}


Appendix E

Project Timeline

\begin{tabular}{|c|c|c|c|c|c|c|c|c|c|c|c|c|c|c|c|c|c|}
\hline & $\begin{array}{l}\mathrm{NU} \\
\mathrm{p} 70\end{array}$ & NUI & 802 & & & & & & & NUR & & & & & & & \\
\hline Activity & 咅 & $\begin{array}{l}\exists \\
\ddot{\sharp} \\
\ddot{3}\end{array}$ & $\frac{\hat{z}}{3}$ & 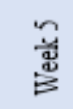 & 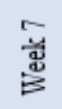 & $\frac{9}{\tilde{u}}$ & $\begin{array}{l}\bar{\Xi} \\
\stackrel{\Xi}{\Xi} \\
\ddot{3}\end{array}$ & $\frac{3}{3}$ & 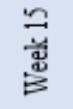 & ت্ّ & 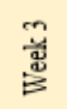 & $\frac{\mathfrak{z}}{2}$ & 产 & $\frac{a}{\tilde{J}}$ & $\begin{array}{l}\exists \\
\vec{\Xi} \\
\text { 岕 }\end{array}$ & $\begin{array}{l}\frac{m}{\Xi} \\
\frac{\pi}{3} \\
3\end{array}$ & 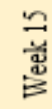 \\
\hline Meet with preceptor & $\mathrm{x}$ & $\mathrm{x}$ & $\mathrm{x}$ & $\mathrm{x}$ & $\mathrm{x}$ & $\mathrm{x}$ & $\mathrm{x}$ & $\mathrm{x}$ & $\mathrm{x}$ & $\mathrm{x}$ & $\mathrm{x}$ & $\mathrm{x}$ & $\mathrm{x}$ & $\mathrm{x}$ & $\mathrm{x}$ & $\mathrm{x}$ & $\mathrm{x}$ \\
\hline $\begin{array}{l}\text { Prepare project } \\
\text { proposal }\end{array}$ & $\mathrm{x}$ & & & & & & & & & & & & & & & & \\
\hline $\begin{array}{l}\text { Plan: } \\
\text { Meet with CCU } \\
\text { manager, medical } \\
\text { director to lay out } \\
\text { project plan }\end{array}$ & & $\mathrm{x}$ & & & & & & & & & & & & & & & \\
\hline $\begin{array}{l}\text { Sleep Enhancement } \\
\text { activities/ protocol/ } \\
\text { bundle approved by } \\
\text { CCU team (NM, } \\
\text { Medical Dir., staff } \\
\text { advocates) }\end{array}$ & & $\mathrm{x}$ & & & & & & & & & & & & & & & \\
\hline $\begin{array}{l}\text { Staff training: } \\
\text { Inservice (see PPT) on } \\
\text { delirium } \\
\text { Reinforce importance } \\
\text { of CAM-ICU use as } \\
\text { indicator of delirium } \\
\text { status }\end{array}$ & & & $\mathrm{x}$ & $\mathrm{x}$ & & & & & & & & & & & & & \\
\hline $\begin{array}{l}\text { Dry-run evaluation of } \\
\text { CAM-ICU use prior to } \\
\text { go-live }\end{array}$ & & & & $\mathrm{x}$ & & & & & & & & & & & & & \\
\hline $\begin{array}{l}\text { Collect CAM-ICU } \\
\text { scores for pts over } 30 \\
\text { days }\end{array}$ & & & & & $\mathrm{x}$ & $\mathrm{x}$ & & & & & & & & & & & \\
\hline Protocol go-live & & & & & & & $\mathrm{x}$ & & & & & & & & & & \\
\hline $\begin{array}{l}\text { Huddle/ staff meeting } \\
\text { check ins for Q\&A }\end{array}$ & & & & & $\mathrm{x}$ & $\mathrm{x}$ & $\mathrm{x}$ & $\mathrm{x}$ & & & & & & & & & \\
\hline $\begin{array}{l}\text { Data collection x } 30 \\
\text { days post- } \\
\text { implementation }\end{array}$ & & & & & & & & $\mathrm{X}$ & $\mathrm{x}$ & & & & & & & & \\
\hline Data analysis & & & & & & & & & & $\mathrm{x}$ & $\mathrm{x}$ & & & & & & \\
\hline Dissemination & & & & & & & & & & & & $\mathrm{x}$ & $\mathrm{X}$ & & & & \\
\hline Write for publication & & & & & & & & & & & & & $\mathrm{x}$ & $\mathrm{x}$ & & $\mathrm{x}$ & \\
\hline $\begin{array}{l}\text { CELEBRATE } \\
\text { SUCCESS } \\
\end{array}$ & & & & & & & & & & & & & & & $\mathrm{x}$ & $\mathrm{X}$ & $\mathrm{x}$ \\
\hline
\end{tabular}




\section{Appendix F}

\section{Projected Budget}

\begin{tabular}{|c|c|c|c|}
\hline \multicolumn{4}{|c|}{ Project Costs } \\
\hline Item & Description & Total Cost & Comments \\
\hline $\begin{array}{l}\text { Salaries for } \\
\text { CCU RNs ( } 40 \\
\text { total) }\end{array}$ & Expense for training: sleep enhancement protocol & $\$ 700.00$ & $\begin{array}{l}\text { Total projected expense for a } 30 \text { minute } \\
\text { training session per RN. Average hourly } \\
\text { rate }=\$ 35.00 \text {. }\end{array}$ \\
\hline \multicolumn{4}{|l|}{ Revenue } \\
\hline $\begin{array}{l}\text { Decreased } \\
\text { delirium }\end{array}$ & $\begin{array}{l}\text { Amount potentially saved with reduced incidence of } \\
\text { delirium (though this project does NOT focus on LOS, } \\
\text { should it be reduced, there would logically be a cost- } \\
\text { savings realized.) }\end{array}$ & $\begin{array}{l}\$ 4300.00 / \text { patient }= \\
\text { average cost of } \\
\text { ICU day }\end{array}$ & $\begin{array}{l}\text { Average cost/day for ICU inpatient stay. } \\
\text { Average ICU LOS }=3.8 \text { days }(\$ 16340) \\
\text { Average daily census }=12 \text { patients with } \\
\text { about } 70 \% \text { delirium rate. }\end{array}$ \\
\hline
\end{tabular}


Appendix G

Data Collection Tool

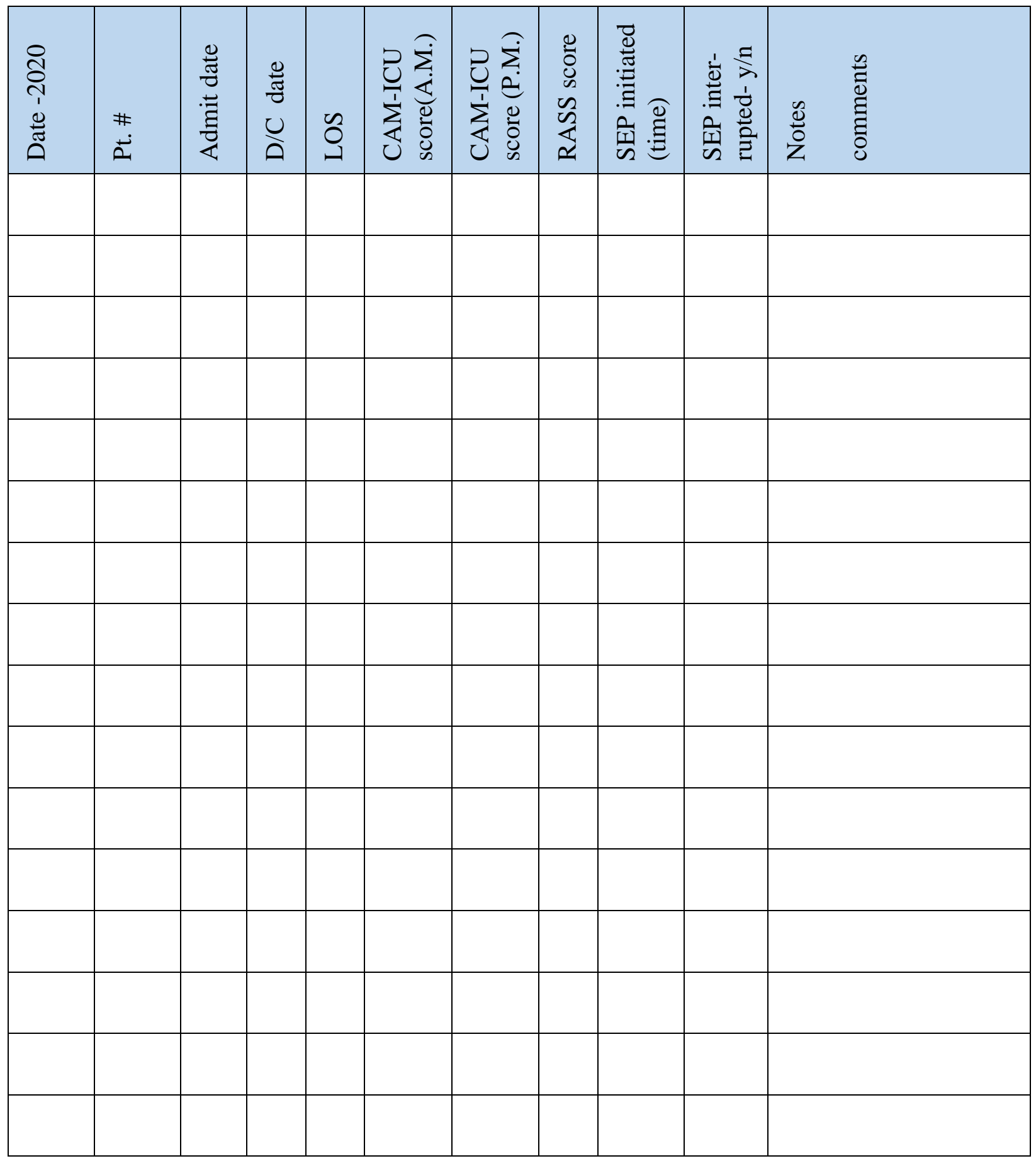




\section{Appendix H}

\section{Confusion Assessment Method-ICU}

\begin{tabular}{|c|c|c|}
\hline Feature 1: Acute Onset or Fluctuating Course & Score & $\begin{array}{l}\text { Check here } \\
\text { if Present }\end{array}$ \\
\hline $\begin{array}{c}\text { Is the patient different than his/her baseline mental status? } \\
\text { OR } \\
\text { Has the patient had any fluctuation in mental status in the past } 24 \text { hours as } \\
\text { evidenced by fluctuation on a sedation/level of consciousness scale (i.e., } \\
\text { RASS/SAS), GCS, or previous delirium assessment? }\end{array}$ & $\begin{array}{c}\text { Either } \\
\text { question Yes } \\
\rightarrow\end{array}$ & . \\
\hline \multicolumn{3}{|l|}{ Feature 2: Inattention } \\
\hline $\begin{array}{l}\text { Letters Attention Test (See training manual for alternate Pictures) } \\
\text { Directions: Say to the patient, "I am going to read you a series of } 10 \text { letters. } \\
\text { Whenever you hear the letter 'A,' indicate by squeezing my hand." Read } \\
\text { letters from the following letter list in a normal tone } 3 \text { seconds apart. } \\
\text { S A V E A H A A R T or C A S A B L A N C A or A B A D B A D A A Y } \\
\text { Errors are counted when patient fails to squeeze on the letter "A" and } \\
\text { when the patient squeezes on any letter other than "A." }\end{array}$ & $\begin{array}{l}\text { Number of } \\
\text { Errors }>2 \rightarrow\end{array}$ & $\square$ \\
\hline \multicolumn{3}{|l|}{ Feature 3: Altered Level of Consciousness } \\
\hline Present if the Actual RASS score is anything other than alert and calm (zero) & $\begin{array}{c}\text { RASS } \\
\text { anything other } \\
\text { than zero } \rightarrow\end{array}$ & $\square$ \\
\hline \multicolumn{3}{|l|}{ Feature 4:Disorganized Thinking } \\
\hline $\begin{array}{l}\text { Yes/No Questions (See training manual for alternate set of questions) } \\
\text { 1. Will a stone float on water? } \\
\text { 2. Are there fish in the sea? } \\
\text { 3. Does one pound weigh more than two pounds? } \\
\text { 4. Can you use a hammer to pound a nail? } \\
\text { Errors are counted when the patient incorrectly answers a question. } \\
\text { Command } \\
\text { Say to patient: "Hold up this many fingers" (Hold } 2 \text { fingers in front of patient) } \\
\text { fingers) "If the patient is unable to move both arms, for } 2^{\text {nd }} \text { part of command ask } \\
\text { patient to "Add one more finger" } \\
\text { An error is counted if patient is unable to complete the entire command. }\end{array}$ & $\begin{array}{l}\text { Combined } \\
\text { number of } \\
\text { errors }>1 \rightarrow\end{array}$ & $\square$ \\
\hline
\end{tabular}

\section{Overall CAM-ICU}

Feature 1 plus 2 and either 3 or 4 present = CAM-ICU positive

\begin{tabular}{|c|c|}
\hline Criteria Met $\rightarrow$ & $\begin{array}{c}\square \\
\text { CAM-ICU } \\
\text { Positive } \\
\text { (Delirium Present) }\end{array}$ \\
\hline Criteria Not Met $\rightarrow$ & $\begin{array}{c}\square \\
\text { CAM-ICU } \\
\text { Negative } \\
\text { (No Delirium) }\end{array}$ \\
\hline
\end{tabular}

https://www.icudelirium.org/medical-professionals/delirium/monitoring-delirium-in-the-icu "We have obtained copyright for the CAM-ICU and its educational materials and have deliberately made it unrestricted in terms of use. We ask that you include the copyright line below on the bottom of the pocket cards and other educational materials, but do not require you to obtain a written letter of permission for implementation and clinical use."

Note. CAM ICU diagram by E. Wesley Ely, MD, MPH, 2002 (http://icudelirium.org). Copyright by Vanderbilt University 


\section{Appendix I \\ Richmond Agitation Sedation Scale}

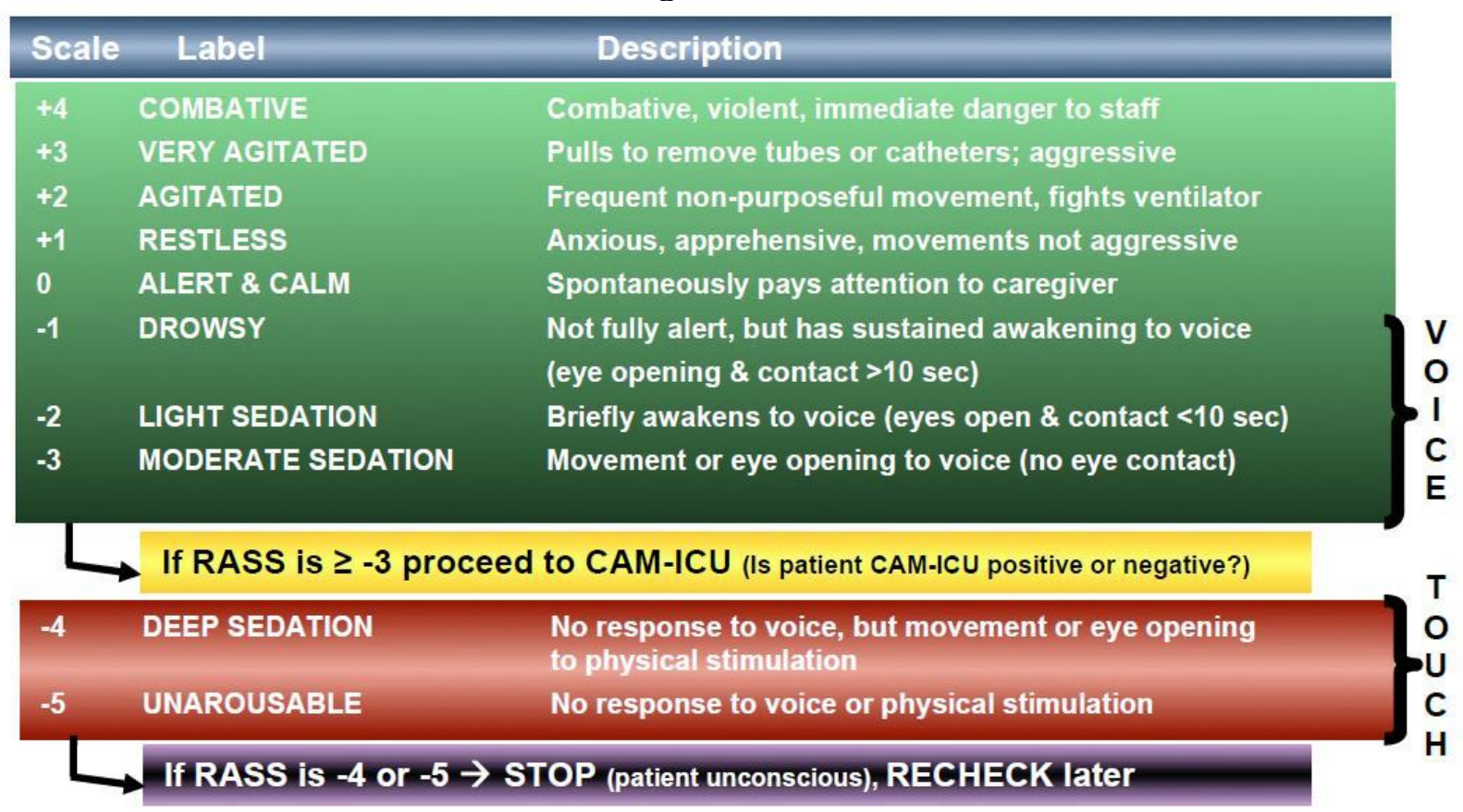

Note. RASS diagram by E. Wesley Ely, MD, MPH, 2002 (http://icudelirium.org). 


\section{Appendix J Staff Inservice PowerPoint}

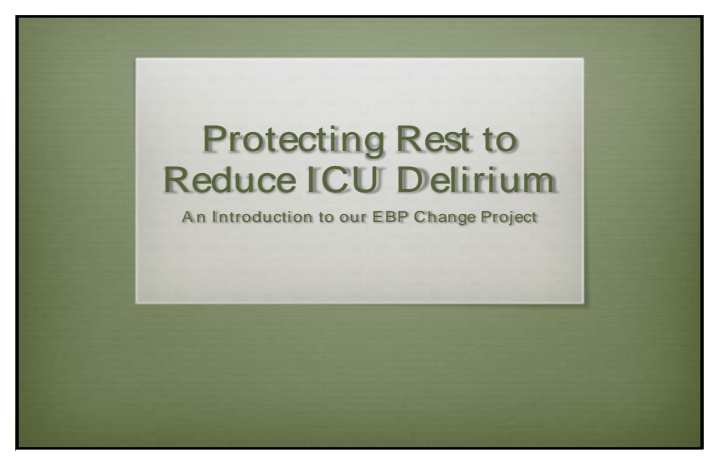

1

Why should we protect rest in the ICU?

* Sleep fragmentation can lead to

$\therefore$ Delirium

* Longer LOS

* ICU

* Hospital

* Higher mortality rate

\& Long-term cognitive impairment

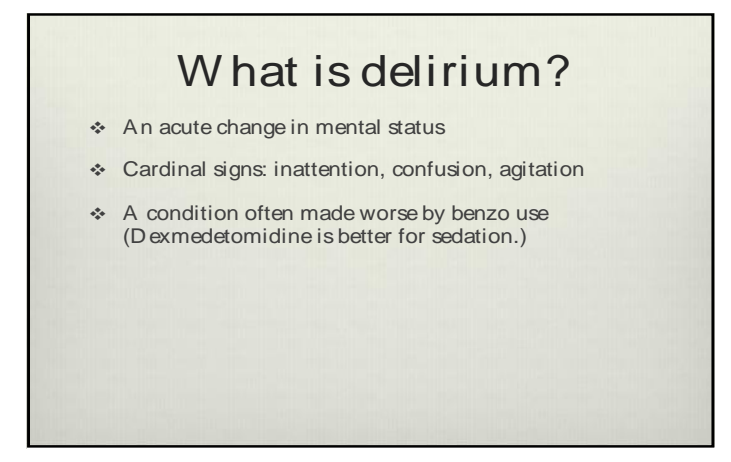

2

\section{Did you know?}

* CAM-ICU is our assessment/ screening tool for confirming the presence of delirium.

* Increasing sedation at night to promote sleep does not shorten the severity or duration of delirium.

- Even if they've had a stroke, have dementia, or are intubated, patients can be screened for delirium.

* There is no pharmacological agent specifically identified as superior for the treatment of delirium.

* Continuous sedation is not required to manage ventilated patients.

\section{PICOT Question}

* For patients in an adult ICU (P), does using a nurseinitiated, non-pharmacological sleep-enhancement protocol (I) versus no sleep-enhancement protocol (C) reduce the incidence of ICU-delirium (O) over two months (T)?
How do we protect rest? Sleep Enhancement Protocol

* Clustering of care for intentional rest periods/ care bundling (No SBT between 0001-0400)

* Avoiding benzodiazepines

* Reorienting frequently Whiteboards can reinforce verbal reorientation

* Manipulating physical environments Noise reduction Closing doors when safe lowering volume on non-essential monitors 


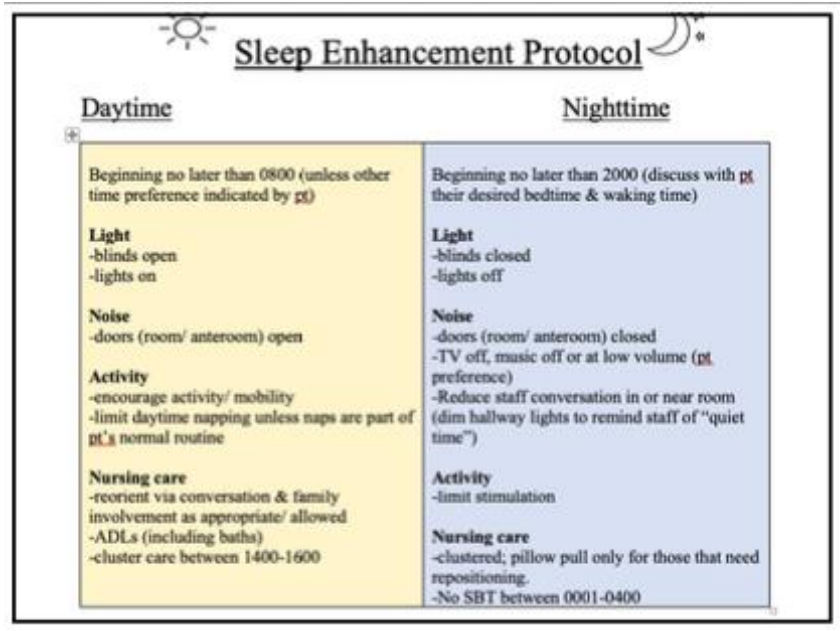

7

\section{Exclusion Criteria}

* Those not counted in the data pool after protocol implementation:

\& Patients admitted $<24$ hours

* Comatose patients

\& Patients who are chemically paralyzed

4 Patients who refuse to participate

\section{References \& Contact Info}

* Available in the project proposal

* Heather J. Thomas

* Heather.thomas4@va.gov

\& 706.799 .9141 


\section{Appendix K \\ Poster Representation of Sleep Enhancement Protocol}

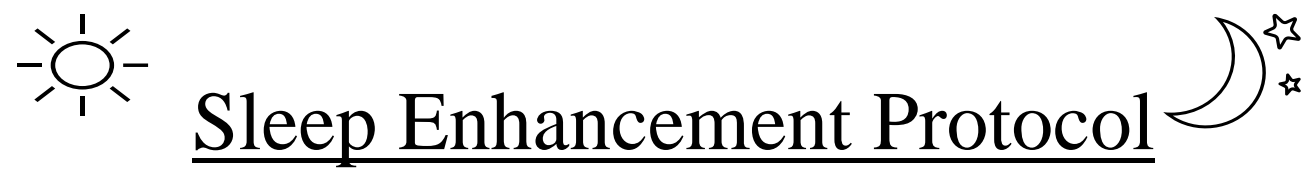

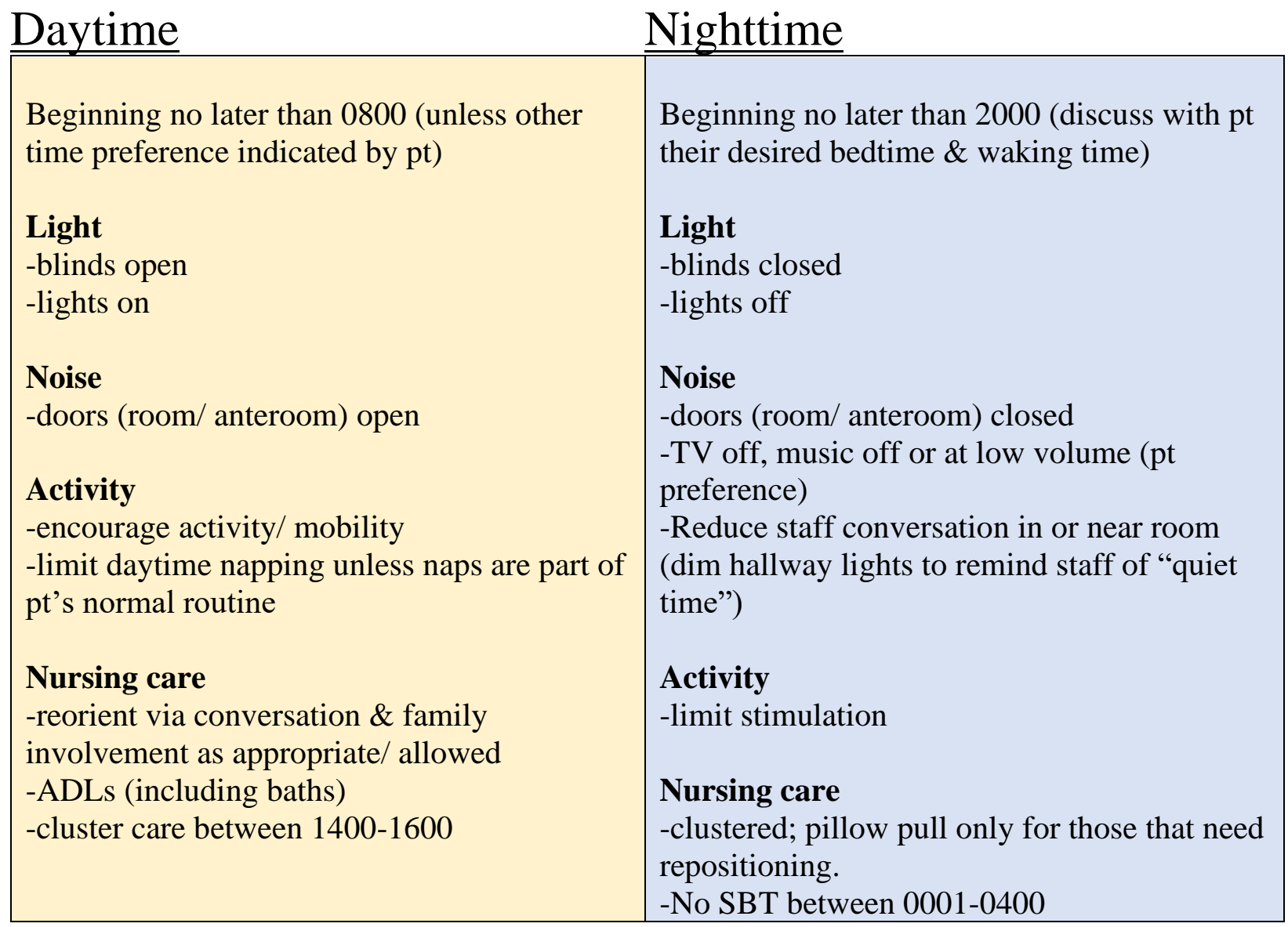




\section{Appendix L}

\section{Letters of Support}

\section{DEPARTMENT OF VETERANS AFFAIRS \\ Charlie Norwood VA Medical Center 1 Freedom Way \\ Augusta, Georgia 30904}

In Reply Refer To:

September, 10, 2020

Sandra Swearingen

Chief of Hospital Education

Charlie Norwood VA Medical Center

Augusta, GA

To whom it may concern:

Please consider this a letter of support for Heather Thomas and her project regarding

delirium in the Adult ICU. This is a very timely project considering that our current climate, due to COVID, is one of familiar isolation, reduced touch, and decreased contact with other humans. This climate alone has a great potential to affect the delirium that many patients experience during hospitalization. Any improvement in patient outcomes will positively impact the lives of our Veterans.

If you have any questions, please feel free to contact me.

Thank you

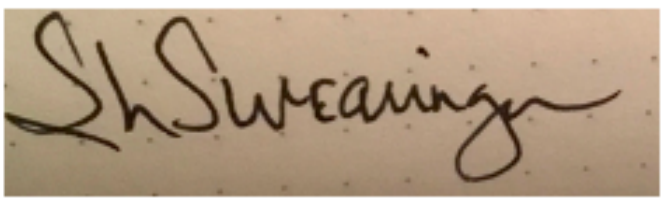




\title{
Department of $\downarrow$ Veterans Affairs
}

\section{Memorandum}

\author{
Date: September 11, 2020 \\ From: Sandra Swearingen, PhD, RN - Chief of Hospital Education \\ Subj: Letter of Support \\ To: Heather Thomas, RN, MSN
}

1. Please consider this as a letter of support for the DNP Project Delirium in Acute Care Patients

2. Due to the increasing amounts of delirium seen today in healthcare, this is felt to be an appropriate project topic for Charlie Norwood VA Medical Center and is supported by myself as her preceptor. Charlie Norwood strives to be a learning organization and is supportive of all educational tracks, especially those in nursing related fields.

3. If you have any questions, please feel free to contact me at 407-506-5524.

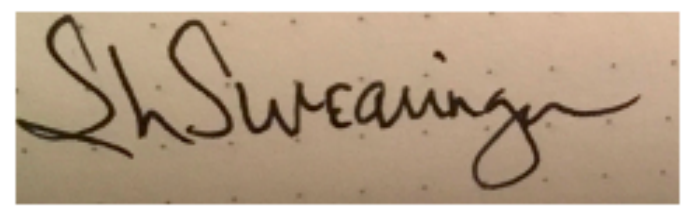

Sandra Swearingen, PhD, RN

Chief of Hospital Education

Charlie Norwood VA Medical Center

Augusta, Ga 